\title{
Impact of invasive alien plant species, Lantana camara, on the species composition, richness and evenness of invaded plant communities in Sidama, Gamogofa and Gedio Zones, Ethiopia
}

Amare Seifu Assefa ( $\square$ ameseifu21@gmail.com )

Addis Ababa University

Ermias Lulekal Molla

Addis Ababa University

\section{Research Article}

Keywords: Control, Diversity, Evenness, Families, Invasions

Posted Date: October 18th, 2021

DOl: https://doi.org/10.21203/rs.3.rs-943114/v1

License: (c) (1) This work is licensed under a Creative Commons Attribution 4.0 International License.

Read Full License 


\section{Abstract}

Invasive alien species represent one of the major threats to biodiversity and all economic sectors. Lantana camara has been ranked as the highest impacting invasive plant species in the study areas. However, its impact on diversity and composition of invaded plant communities has not been well studied. Therefore, the objective of this study was to investigate the impact of Lantana camara on species diversity and composition of invaded plant communities in the study areas. A total of $120,10 \mathrm{~m} \mathrm{X}$ $10 \mathrm{~m}$ plots were sampled so as to examine its effects of invasions on the species diversity and composition of invaded communities. A total of 109 species were found in the non-invaded areas as compared to 56 in the invaded areas. The number of species decreased by $48.6 \%$ in Lantana camara invaded areas as compared to the control. The mean evenness values of the entire invaded sampled study site and that of the control were 0.24 and 0.81 respectively. Thus, the heterogeneity of the invaded study sites was reduced by $57 \%$. The number of plant families was 44 in the control areas in contrast to only 30 in the invaded areas. The number of plant families decreased by $31.8 \%$ in the invaded areas as compared to the control. Therefore, it was noted that Lantana camara has a serious impact on plant diversity hence the finding calls for an urgent management and control strategy against the spread of Lantana camara so as to save the ongoing threat to biodiversity.

\section{Introduction}

Invasive alien species (IASs) represent one of the primary dangers to biodiversity, human health and all economic sectors, especially in developing countries (Hejda et al., 2009).It has become one of the main causes of economic and ecological damage in most of the countries across the world (Paini et al., 2016). Almost, all ecosystem types on the planet are affected by IASs and they pose one of the biggest threats to biodiversity next to habitat destruction (GEF, 2003, Genovesi and Shine, 2004). Globally, the cost of damage caused by IASs has been estimated to be $£ 1.5$ trillion per year - close to $5 \%$ of global Gross Domestic Product (GDP). In developing countries, where agriculture accounts for a higher proportion of GDP, the negative impact of IASs on food security as well as on economic performance can be even greater which affect human well-being, contributing to lower food security, harsher living conditions, reduced wealth, social instability and poverty alleviation (IUCN, 2009, BIOCEM-RD, 2016 and Shaheen, 2019).

Globalization through increased trade, transport, travel and tourism will inevitably increase the intentional introduction of organisms to new environments. Various IASs have been introduced to Ethiopia, like other countries in the tropics. Recently, in Ethiopia there are more than 35 Invasive Alien Plant species(IAPSs) spreading at alarming rate, threatening agricultural lands, power dams, rangelands, national parks, lakes, rivers and roadsides. IASs have been identified by the Environmental Policy of Ethiopia (EPE) and the National Biodiversity Strategy and Action Plan (NBSAP) as posing a major threat to biodiversity and economic well-being of the country. Parthenium weed (Parthenium hysterophorus), Prosopis juliflora, Water hyacinth (Eichhornia crassipes) and Lantana weed (Lantana camara) are the most known IAPSs in Ethiopia (Rezene Fessehaie and Taye Tessema ,2014). 
Lantana camara L. is one of the worst IAPS worldwide. It is erect and a hardy evergreen perennial shrub up to $5 \mathrm{~m}$ tall. It is a species of flowering plant within the verbenaceae family. It is native to tropical and subtropical America and the West Indies. It is common as an ornamental plant in all parts of the Flora of Ethiopia within an altitudinal range of 500 to 2500 meter above sea level (Sebsebe Demissew and Hedberg, 2006). The distribution of Lantana camara in Ethiopia is great and many ecosystems are affected by this species are cultivated and non-cultivated land, road side, grazing area, rural villages, river side, wetlands, forest and urban areas . It causes the loss of maximum amount biodiversity (Aravind et al.,2010, Habtamu Kefelegn, 2015, Kumar et al.,2016).

Lantana camara has usually been deliberately introduced into various localities in Ethiopia (particularly urban settings) as an ornamental shrub and has been quickly spread by birds and animals that eat its fruits but cannot digest the woody seeds (Abiyu Enyew and Raja, 2015). In Ethiopia, it is one of the four major IAPSs those posing negative impacts on country's biodiversity. However, no adequate latest evidence exists about the impact of Lantana camara on species diversity (evenness and richness) and composition. Therefore, this study aims to assess the impact of Lantana camara on the species diversity and composition of invaded plant communities in Sidama, Gamogofa and Gedio Zones, SNNPR, Ethiopia.

\section{Materials And Methods}

\section{Description of the study areas}

The study was conducted in the three Zones (Gedio, Sidama and Gamogofa ) of SNNPR. Gedio zone is located in North eastern part of the region, It roughly lies between $60^{0} 59-60^{\prime} 62^{\prime \prime} \mathrm{N}$, latitude and $38^{\circ} 40$ 380 '.43" E, longitude. The altitude ranges from 1500 to 3000 meter above sea level. Sidama is also located in the north eastern part of the region. Its geographic location lies between $6^{0} 14^{\prime}$ and $7^{0} 18^{\prime} \mathrm{N}$, latitude and $37^{\circ} 92^{\prime}$ and $39^{\circ} 14^{\prime} \mathrm{E}$, longitude with an elevation ranges from 1500 and $2500 \mathrm{~m}$ above sea level (Zebene Asfaw and Agren, 2007). Gamo-Gofa zone is named for the Gamo and Gofa peoples, whose homelands lie in this Zone. The administrative center of this zone is Arba Minch (Vaughan, 2003).

\section{Materials}

The common equipment and tools used in voucher specimen collection during the study were clippers, field press, newspapers, pencils, camera, measuring tape, diggers, GPS, study location and documentation data form.

\section{Method of data collection}

This study was conducted between January 2020 and August 2020 in Sidama, Gedio and Gamogofa Zones, South Nation Nationality People Regional government (SNNPR), Ethiopia. The study zones and districts were selected purposively on the basis of the level of Lantana camara invasion with the help of information obtained from Agricultural office of Sidama, Gedio and Gamo-Gofa Zones. Based on the 
above selection criteria, from the three zones, three districts were selected. In each Zone one district was selected. Mirab Abaya, Dilla Zuria and Dara districts were selected from Gamo-Gofa, Gedio and Sidama respectively. From each district one kebele( the smallest administrative zone in Ethiopia) was selected. From Mirab Abaya, Woze Kebele was selected while from Dara and Dilla zuria Mechisho and Waleme kebele were selected respectively. In Each Kebele Community forest areas were selected. Accordingly, Woze,Mechisho and Waleme kebele community forests were selected. The impact of Lantana camara on the species diversity and composition of invaded plant communities was studied by applying Quadrat Method following (Hejda et al.,. 2009, Dogra et al., 2009, Lisanework Nigatu,2010).

\section{Sampling Techniques}

To examine the effects of Lantana camara invasions on the species diversity and composition of invaded communities, a total of $120,10 \mathrm{mX} 10 \mathrm{~m}$ quadrats were sampled (60 quadrats for invaded and 60 quadrats for un-invaded or control). In each selected district 40 quadrats were laid (20 quadrats for invaded and 20 for non-invaded). In each selected study Kebele, a single quadrat of the set was placed in severely annexed plant communities ("invaded quadrat") where the aggressor was dominant and had a high concealment, and the next quadrat was located in adjacent plant community where Lantana camara had no cover (control) purposively. As much as possible, the control was selected to have analogous site conditions (<10 m) to the invaded quadrat following (Hejda et al., 2009 and Dogra et al., 2009). The location of each quadrat and study sites were recorded with GPS.

A control was selected in order to compare the species richness, evenness and composition of plant communities in the invaded and non-invaded areas. All the plant species appeared in the invaded and control areas were sampled and identified. Most of the plant species discovered in the quadrats was identified in the field. For species difficult to identify in the field, voucher specimens were collected, pressed and dried properly and transported to Ethiopian Biodiversity Institute for identification and proper naming. The nomenclature of the plant species followed the Flora of Ethiopia and Eritrea.

\section{Method of data analysis}

The collected data was analyzed by using SPSS (version 21) and R-package (version 3.6.2). A descriptive statistical method was employed to analyze and summarize the data. Inferential statistical method was also employed. Linear Regression Analysis was used to predict the value of a variable based on the value of another variable. The percentage and number of Lantana camara per study site and per quadrat was taken as the independent variables while diversity of plant species, Species richness, Simpson_1-D dominance index, Shannon-H diversity index and Evenness were taken as the dependent variable or outcome variable. Results were also statistically analyzed by PCA to extract the significant correlations from species data set or the correlation between a row (site/plots) and a column (the plant species/variable).

Plant species diversity analysis (Shannon1949, $\mathrm{H}^{\prime}$ ) and richness and evenness of each study sites were analyzed. Evenness was calculated as $\mathrm{H}^{\prime} / \mathrm{lnS}$, where $\mathrm{S}$ is the species richness expressed as the number of species (Hejda et al., 2009). Simpson index of dominance is calculated using the formula, $D=N(N-1) / \Sigma n i$ 
(ni-1) Where ni is the number of individuals in the $\mathrm{i}^{\text {th }}$ plant species; $\mathrm{N}$ is the total number of individuals (Barrantes and Sandoval, 2009). Changes in species richness S, Simpson 1-D index of dominance, Shannon index of diversity $\mathrm{H}^{\prime}$ and evenness between invaded and control quadrats were used to quantity the influence of invasion on these plant communities' characteristics. These changes in plant communities' characteristics between invaded and control sites were used as a measure of the impact of invasion on species richness, evenness, index of dominance, and calculated and compared to find out the loss of plant diversity due to invasion of Lantana camara.

\section{Tests of association}

Various inferential statistical tests were performed on the different types of data collected. The significance impacts of the number of Lantana camara on diversity of plant species had been also tested with one way ANOVA, while the differences in Margalef's index of species richness, evenness, Simpson and Shannon-H index of diversity between invaded and un-invaded areas were checked with the help of $t$ test following Wambua(2010).

\section{Results}

Impact of Lantana camara on species evenness and richness in the study areas

In the present study there were found a total of 109 species in the control or un-invaded areas as compared to 56 in Lantana camara invaded areas. Hence, the number of species lessened by $48.6 \%$ in the Lantana camara invaded localities as compared to the control. Simpson_1-D index of dominance, Shannon_ $\mathrm{H}$ index diversity, Margalef's index of species richness, and evenness index were also reduced via $66.04 \%, 74.48 \%, 51.95 \%$ and $57 \%$ respectively in the Lantana camara invaded areas(Table 1 ).

Table 1

Values of index of diversity for Invaded and non-invaded floral communities

\begin{tabular}{|lllll|}
\hline \multicolumn{3}{|l}{ For invaded floral communities } & \multicolumn{2}{l|}{ For non-invaded floral communities } \\
\hline No. & Index of diversity & Values & Index of diversity & Values \\
\hline 1 & Taxa_S & 56 & Taxa_S & 109 \\
\hline 2 & Individuals & 6720 & Individuals & 4088 \\
\hline 3 & Dominance_D & 0.67 & Dominance_D & 0.04 \\
\hline 4 & Simpson_1-D & 0.33 & Simpson_1-D & 0.96 \\
\hline 5 & Shannon_H & 0.97 & Shannon_H & 3.81 \\
\hline 6 & Margalef & 6.24 & Margalef & 12.99 \\
\hline 7. & Equitability (evenness) & 0.24 & Equitability (evenness) & 0.81 \\
\hline
\end{tabular}


The mean Evenness value or Equitability_J of the entire invaded sampled study sites was 0.24 indicated that $24 \%$ of the plant communities had uniform distribution while the mean Evenness value of the controls (the entire un-invaded) samples was 0.81 indicated that $81 \%$ of the plant communities had uniform distribution. Thus, the heterogeneity of the invaded study sites was reduced by $57 \%$.

Table 2

Impact of Lantana camara on the plant communities

\begin{tabular}{|lllll|}
\hline No. & Parameters & $\begin{array}{l}\text { Control/un- } \\
\text { invaded }\end{array}$ & Invaded & $\begin{array}{l}\text { \% reduction over } \\
\text { control }\end{array}$ \\
\hline 1. & Richness(Total Species) & 109 & 56 & $48.6 \%$ \\
\hline 2. & $\begin{array}{l}\text { Simpson's Index of Dominance (I- } \\
\text { D) }\end{array}$ & 0.96 & 0.33 & $66.04 \%$ \\
\hline 3. & Shannon's Index of Diversity (H') & 3.81 & 0.97 & $74.48 \%$ \\
\hline 4. & Margalef Index of Richness(R) & 12.99 & 6.24 & $51.95 \%$ \\
\hline 5. & Index of Evenness (Es) & 0.81 & 0.24 & $57.00 \%$ \\
\hline
\end{tabular}

From the study districts, Dara, Mechisho Kebele community forest, was harshly affected by the invasion of Lantana camara. In this Kebele community forest, the number of species decreased by $66.15 \%$ in the Lantana camara invaded area as compared to control. Further, Simpson_1-D index of dominance, Shannon_ $\mathrm{H}$ index diversity, Margalef's index of species richness, and evenness index were reduced by $78.44 \%, 83.99 \%, 70.16 \%$ and $78.39 \%$ respectively in the Lantana camara invaded areas (Table 3).

Table 3

Invaded and Control Floral Communities of Mechisho Kebele community

\begin{tabular}{|lllll|}
\hline No. & Invaded Dara & & \multicolumn{2}{l|}{ Non Invaded Dara/control } \\
\cline { 2 - 5 } & Diversity Index & Values & Diversity Index & Values \\
\hline 1. & Taxa_S & 22 & Taxa_S & 65 \\
\hline 2. & Individuals & 2902 & Individuals & 1408 \\
\hline 3. & Dominance_D & 0.79 & Dominance_D & 0.04 \\
\hline 4. & Simpson_1-D & 0.21 & Simpson_1-D & 0.96 \\
\hline 5. & Shannon_H & 0.58 & Shannon_H & 3.60 \\
\hline 6. & Margalef & 2.63 & Margalef & 8.83 \\
\hline 7. & Equitability_J & 0.19 & Equitability_J & 0.86 \\
\hline
\end{tabular}

Concerning to Woze kebele community forest, the number of species decreased by $52.94 \%$ in the Lantana camara invaded area as compared to control. In addition, Simpson_1-D index of dominance, Shannon_H 
index diversity, Margalef's index of species richness, and evenness index were reduced by $65 \%, 68.55 \%$, $54.49 \%$ and $60 \%$ respectively in the Lantana camara invaded areas as compared to control (Table 4).

Table 4

Invaded and Non Invaded Floral Communities of Woze kebele community forest

\begin{tabular}{|cllll|}
\hline No. & Invaded & \multicolumn{3}{l|}{ Non- Invaded /control } \\
\cline { 2 - 5 } & Diversity Index & Values & Diversity Index & Values \\
\hline 1. & Taxa_S & 16 & Taxa_S & 34 \\
\hline 2. & Individuals & 3269 & Individuals & 2309 \\
\hline 3. & Dominance_D & 0.69 & Dominance_D & 0.13 \\
\hline 4. & Simpson_1-D & 0.31 & Simpson_1-D & 0.87 \\
\hline 5. & Shannon_H & 0.77 & Shannon_H & 2.44 \\
\hline 6. & Margalef & 1.85 & Margalef & 4.26 \\
\hline 7. & Equitability_J & 0.28 & Equitability_J & 0.69 \\
\hline
\end{tabular}

On the other hand, Dilla Zuria (forests in Waleme area) was the least affected by the invasion of Lantana camara. In this areas, the number of species decreased by $31.48 \%$ in the Lantana camara invaded area as compared to control. Moreover, Simpson_1-D index of dominance, Shannon_H index diversity, Margalef's index of species richness, and evenness index were reduced by $32.89 \%, 47.83 \%, 31.78 \%$ and $42.36 \%$ respectively in the Lantana camara invaded areas as compared to control (Table 5).

Table 5

Comparisons of various diversity indexes in Invaded and control of Waleme Kebele community forest

\begin{tabular}{|cllll|}
\hline No. & Invaded & \multicolumn{3}{l|}{ Non Invaded/control } \\
\cline { 2 - 5 } & Diversity Index & Values & Diversity Index & Values \\
\hline 1. & Taxa_S & 37 & Taxa_S & 54 \\
\hline 2. & Individuals & 1478 & Individuals & 1524 \\
\hline 3, & Dominance_D & 0.39 & Dominance_D & 0.09 \\
\hline 4. & Simpson_1-D & 0.61 & Simpson_1-D & 0.91 \\
\hline 5. & Shannon_H & 1.56 & Shannon_H & 2.99 \\
\hline 6. & Margalef & 4.93 & Margalef & 7.23 \\
\hline 7. & Equitability_J & 0.43 & Equitability_J & 0.75 \\
\hline
\end{tabular}


Generally, the reduction over control on the plant diversity, Simpson_1-D index of dominance, Shannon_H index diversity, Margalef's index of species richness and evenness index were highest in Mechisho kebele followed by Woze and Waleme kebeles respectively (Table 6). This could be due to the substantial impact of Lantana camara invasion in the stated study areas.

Table 6

The decline on the plant diversity, Richness, and Evenness (E) of Lantana camara invaded plant communities over control in each of the study Kebele.

\begin{tabular}{|c|c|c|c|c|c|}
\hline No. & Name of study site & Parameters & Control/un-invaded & Invaded & $\%$ decline over control \\
\hline \multirow[t]{5}{*}{1.} & \multirow[t]{5}{*}{ Woze } & C & 34 & 16 & $52.94 \%$ \\
\hline & & I-D & 0.87 & 0.31 & $65.05 \%$ \\
\hline & & ' $\mathrm{H}$ ' & 2.44 & 0.77 & $68.55 \%$ \\
\hline & & $\mathrm{R}$ & 4.26 & 1.85 & $56.49 \%$ \\
\hline & & E & 0.69 & 0.28 & $60.00 \%$ \\
\hline \multirow[t]{5}{*}{3.} & \multirow[t]{5}{*}{ Waleme } & C & 54 & 37 & $31.48 \%$ \\
\hline & & I-D & 0.91 & 0.61 & $32.89 \%$ \\
\hline & & 'H' & 2.99 & 1.56 & $47.83 \%$ \\
\hline & & $\mathrm{R}$ & 7.23 & 4.93 & $31.78 \%$ \\
\hline & & E & 0.75 & 0.43 & $42.36 \%$ \\
\hline \multirow[t]{5}{*}{4.} & \multirow[t]{5}{*}{ Mechisho } & C & 65 & 22 & $66.15 \%$ \\
\hline & & I-D & 0.96 & 0.21 & $78.44 \%$ \\
\hline & & 'H' & 3.6 & 0.58 & $83.99 \%$ \\
\hline & & $\mathrm{R}$ & 8.83 & 2.63 & $70.16 \%$ \\
\hline & & E & 0.86 & 0.19 & $78.39 \%$ \\
\hline
\end{tabular}

\section{Relationships between percentage of Lantana camara and species diversity in the study areas}

The regression analysis showed a strong negative relationship between the coverage (percentage) of Lantana camara and Simpson_1-D index of diversity per quadrat. Hence, the regression equation can be presented as:

$\mathrm{Y}=-0.0112 \mathrm{X}+1.1924$, where $\mathrm{Y}$ is Simpson_1-D index of diversity and $\mathrm{X}$ is percentage of Lantana camara per quadrat. In this case, $R^{2}=0.9117$ or $91.17 \%$ of the dependent variable (Simpson_1-D index of diversity) can be explained by the independent variable (coverage of Lantana camara). The regression 
equation and the value of $\mathrm{R}^{2}$ indicated there was a strong negative relationship between the percentage of Lantana camara and Simpson_1-D index of diversity. As the percentage of Lantana camara increase Simpson_1-D index of diversity decease (Fig. 2).Similarly, there was strong negative relationship between the percentage of Lantana camara and Simpson_1-D index of diversity per study kebele $(Y=-0.013 X+$ 1.406 with $\mathrm{R}^{2}=0.998$ ) (Fig. 3).

There was also a strong negative linear relationship between Shannon_H index diversity and the percentage of Lantana camara per study quadrat and kebele $\left(Y=-0.0201 X+2.2128, R^{2}=0.8471\right.$ and $Y=-0.0332 X+3.466, R^{2}=0.9999$ respectively). Generally, Shannon_H index diversity decreased with the corresponding increase in the percentage of Lantana camara (Figs. 4 and 5).

The regression analysis also showed a negative relationship between the coverage of Lantana camara and species richness per quadrat . Hence, the regression equation can be presented as: $Y=-0.0398 \mathrm{X}+$ 7.3319 , where $Y$ is species richness and $X$ is percentage of Lantana camara per quadrat. The regression equation indicated that there was a negative relationship between the coverage of Lantana camara and species richness. As percentage of Lantana camara increased species richness deceased (Fig. 6). In this case, $\mathrm{R}^{2}=0.2601$ or $26.01 \%$ of the dependent variable (species richness) can be explained by the independent variable (coverage of Lantana camara).

Moreover, there also existed strong negative linear relationship between percentage of Lantana camara and species evenness per study kebele, hence, the regression equation can be presented as: $Y=-0.0077 \mathrm{X}$ +0.892 , where $\mathrm{Y}$ is species evenness and $\mathrm{X}$ is percentage of Lantana camara per study kebele. In this case, the regression equation and $\mathrm{R}^{2}\left(\mathrm{R}^{2}=0.967\right.$, or $\left.96.7 \%\right)$ indicated that there was a strong negative relationship between the coverage of Lantana camara and species evenness per study kebele or $96.7 \%$ of the dependent variable (species evenness) can be explained by the independent variable (coverage of Lantana camara). As the coverage of Lantana camara increased, species evenness per study kebele decreased (Fig. 7)

Study Invaded Kebele $\left(\mathrm{R}^{2}=0.967, p<0.01\right)$.

The results indicated that there was also strong negative linear relationship between the coverage of Lantana camara and evenness of plant species per quadrat. Hence, the regression equation can be presented as: $\mathrm{Y}=-0.0117 \mathrm{X}+1.3546$, where $\mathrm{Y}$ is evenness and $\mathrm{X}$ is percentage of Lantana camara per study quadrat. In this case, $\mathrm{R}^{2}=0.8662$, or $86.62 \%$ of the dependent variable (species evenness per study quadrat) can be explained by the independent variable (coverage of Lantana camara). Therefore, the regression equation and $\mathrm{R}^{2}$ value indicated that there was a strong negative relationship between the coverage (percentage) of Lantana camara and evenness of plant species (Fig. 8).

Plants per invaded quadrat $\left(\mathrm{R}^{2}=0.8662, p<0.01\right)$. 
Furthermore, $t$-test on differences in Simpson diversity Index $(t=-4.8429, d f=11, p$-value $=0.00052)$, Shannon_Evenness $(\mathrm{t}=-4.4912, \mathrm{df}=11, \mathrm{p}$-value $=0.00091)$, Margalef $(\mathrm{t}=-4.7824, \mathrm{df}=11, \mathrm{p}$-value $=$ $0.00057)$ and Richness $(t=-5.304, d f=11, p$-value $=0.00025)$, between invaded and un-invaded study areas showed that there was significant difference in species diversity ( $t$-test, with $p$-value $<0.05$ ) between invaded and non-invaded study areas.

\section{Relationship between diversity of plant species and number of individuals Lantana camara per quadrat}

The study proved that there were considerable variations in the numbers of Lantana camara and diversity of plant species per plot which could be able to make a model to show the severity of the invasion. Both the numbers of Lantana camara and diversity of plant species contribute to the model. As the number of Lantana camara increased, the varieties of plant species decreased. $\mathrm{R}^{2}$ value indicates how much of the dependent variable (diversity of plant species) can be explained by the independent variables (number of Lantana camara).To determine the degree of impact of Lantana camara on diversity plant species linear regression analysis was conducted. The regression equation that describes a simple linear regression relationship in a population is expressed as: $Y i=a+\beta X i+\varepsilon i$ Where $a$ is the intercept and $\beta$ is the slope of the relationship, $\varepsilon i$ is referred as residual or error term and it is the departure of an actual (measured) $Y$ from the estimated $Y$ using the above regression equation $(\widehat{Y})$ (Barrantes and Sandoval,2009, Pallant,2011).In this study, $\mathrm{Yi}$ is the dependent variable (diversity of plant species) and $\mathrm{Xi}$ is the independent variable (number of individual Lantana camara).

Hence, the regression equation can be presented as: $Y=-0.0386 X+9.1994$, where $Y$ is diversity of plant species and $X$ is number of Lantana camara. In this case, $R^{2}=0.6168$, or $61.68 \%$ of the dependent variable (diversity of plant species) can be explained by the independent variable (number of Lantana camara) .The regression equation and Pearson correlation (-0.785) indicated the existence of strong negative linear relationship between diversity of plant species and number of Lantana camara (Fig. 9).

The number of Lantana camara per plot (sig.0.000) had significant influence on the diversity of plant species. Furthermore, there was an inverse relationship between the diversity of plant species and number of Lantana camara per each selected study kebele. For instance, the regression equation can be presented as: $Y=-0.091 X+10.591, R^{2}=0.614$ for Waleme kebele (Fig. 10) and $Y=-0.03 X+7.064, R^{2}=$ 0.611 , Woze kebele (Fig. 11) community forest where $Y$ is diversity of plant species and $X$ is number of Lantana camara. Therefore, the regression equation and $\mathrm{R}^{2}$ values indicated the existence of strong negative linear relationship between diversity of plant species and number of Lantana camara.

Generally this study indicated that plant species diversity in Lantana camara invaded areas was low. There was significant variation in plant species diversity between the invaded and non- invaded plant community in the study areas $(t=-4.2839, \mathrm{df}=59, \mathrm{p}$-value $=6.868 \mathrm{e}-05$ which is $<0.05)$. The significance impacts of the number of Lantana camara on diversity of plant species had been also conducted with the help of One way ANOVA which revealed that number of Lantana camara had significant impact on the diversity of plant species $(F=126.62, d . f=1, P$ value $=3.267 \mathrm{e}-16$ which is $P<0.05$. 
Principal Component Analysis (PCA) was also conducted for invaded and non-invaded floral communities of the study areas. As to the non-invaded floral communities, the first two principal components (PC1 and PC2) together accounted for $31.6 \%$ of the total variance in data set or $19.9 \%$ and $11.7 \%$ variance were accounted by the first and second principal components, respectively following by the third principle components. Majority of the species were at the origin or at their average values especially in non-invaded study sites. Moreover, the PCA biplot axis, indicated the separation of the common plant species including Solanum incanum, Datura stramonium, Amaranthus caudatus, Ageratum conyzoides, Ziziphus abyssinica,Osyris quadripartita, Acacia abyssinica, Achyranthes spp., Stephania abyssinica and Acacia saligna (Fig. 12).

Concerning to the invaded floral communities, majority of the plots were close together. Moreover, the invaded study areas the first, second and third principle components accounted by $16.7 \%, 12.3 \%$ and $10.9 \%$ of the total variance in data set respectively. Therefore, the first three principal components together accounted for $39.9 \%$ of the total variance in data set (Fig. 13). On the other hand, plots 52, 53 and 55 were far apart to each other's and from the other plots.

\section{Impact of Lantana camara on the composition of plant species in the study areas}

Lantana camara invasion heavily damaged the composition and structure of invaded floral communities in the study areas. In this study a comparison in floristic composition was made between Lantana camara invaded and non-invaded areas. An entire of 125 plant species(56 plant species in invaded,109 in control and 38 common to both) belonging to 49 families of plants were identified in this study. From the total plant families 44 of them were recorded in the control area in contrast to only 30 in the Lantana camara invaded areas. The number of family decreased via $31.82 \%$ in the Lantana camara invaded area as compared to control.

In invaded areas, of the 30 plant families, Fabaceae was the highest $(14.29 \%)$, followed by Euphorbiaceae (8.93 \%), and Malvaceae and Myrsinaceae accounted 7.14\% each allotting the third place amongst the plant species recorded in the Lantana camara invaded study areas (Table 7). In the invaded areas $37.5 \%$ of the plant species placed within these four common families.

Table 7

The four most common families in the invaded study sites

\begin{tabular}{|lll|}
\hline No. & Families & Number of species in the given family percentage \\
\hline 1. & Fabaceae & 814.29 \\
\hline 2. & Euphorbiaceae & 58.93 \\
\hline 3. & Malvaceae & 47.14 \\
\hline 4. & Myrsinaceae & 47.14 \\
\hline
\end{tabular}


In non-invaded areas, of the 44 plant families, Fabaceae was the highest (15.74\%), followed by Asteraceae (10.18\%), Malvaceae (5.71\%) apportioning the third place, and Euphorbiaceae and Celastraceae (4.63\%) each allocating the fourth place amongst the plant species recorded in the noninvaded study areas (Table 8 ). These five families shared $40.89 \%$ of species to the over-all flora in noninvaded (controlled) study sites.

Table 8

The seven most common families in three non-invaded study sites (in the control)

\begin{tabular}{|lll|}
\hline No. & Family & Number of species in the given family Percentage \\
\hline 1. & Fabaceae & 1715.74 \\
\hline 2. & Asteraceae & 1110.18 \\
\hline 3. & Malvaceae & 65.71 \\
\hline 4. & Celastraceae & 54.63 \\
\hline 5. & Euphorbiaceae & 54.63 \\
\hline 6. & Lamiaceae & 43.67 \\
\hline 7. & Acanthaceae & 43.67 \\
\hline
\end{tabular}

From 125 plant species identified during the study, 38 plant species were found common in control and invaded areas (Table 9). Lantana camara was found to be the most dominant plant species in invaded study sites followed by Solanum incanum, Achyranthes aspera and Parthenium hysterophorus respectively. Trees and shrubs (78.4\%) were the major plant species identified during this study. In invaded and control (non- invaded) areas $44 \%$ and $34.4 \%$ were shrubs and trees respectively.

Table 9. Plant species composition in the control and invaded areas. 


\begin{tabular}{|c|c|c|c|c|c|}
\hline No. & Scientific name & Family & C con & Control & Invaded \\
\hline 1. & Acacia abyssinica. & Fabaceae & $\sqrt{ }$ & & $\sqrt{ }$ \\
\hline 2. & Acacia oerfota. & Fabaceae & $\sqrt{ }$ & & $\mathrm{x}$ \\
\hline 3. & Acacia.bussei. & Fabaceae & $\sqrt{ }$ & & $\mathrm{x}$ \\
\hline 4. & Acacia saligna & Fabaceae & $\sqrt{ }$ & & $\mathrm{x}$ \\
\hline 5. & Acacia Senegal & Fabaceae & $\sqrt{ }$ & & $\mathrm{x}$ \\
\hline 6. & Acacia seyal & Fabaceae & $\sqrt{ }$ & & $\mathrm{x}$ \\
\hline 7. & Acacia Spp. & Fabaceae & $\sqrt{ }$ & & $\mathrm{X}$ \\
\hline 8. & Acacia tortilis & Fabaceae & $\sqrt{ }$ & & $\sqrt{ }$ \\
\hline 9. & Acanthus spp & Acanthaceae & $\sqrt{ }$ & & $\sqrt{ }$ \\
\hline 10. & Achyranthes spp. & Amaranthacea & $\sqrt{ }$ & & $\mathrm{x}$ \\
\hline 11. & Achyranthes aspera & Amaranthaceae & $\sqrt{ }$ & & $\sqrt{ }$ \\
\hline 12. & Acokanthera schimperi & Apocynaceae & $\sqrt{ }$ & & $\sqrt{ }$ \\
\hline 13. & Agave sisalana & Agavaceae & $\sqrt{ }$ & & $\sqrt{ }$ \\
\hline 14. & Ageratum conyzoides & Asteraceae & $\sqrt{ }$ & & $\mathrm{x}$ \\
\hline 15. & Ajuga Spp. & Lamiaceae & $\sqrt{ }$ & & $x$ \\
\hline 16. & Aloe Spp. & Aloaceae & $\sqrt{ }$ & & $\sqrt{ }$ \\
\hline 17. & Amaranthus caudatus. & Amaranthaceae & $\sqrt{ }$ & & $x$ \\
\hline 18. & Argemone ochroleuca & Papaveraceae & $\sqrt{ }$ & & $\mathrm{x}$ \\
\hline 19. & Asparagus officinalis & Asparagaceae & $x$ & & $\sqrt{ }$ \\
\hline 20. & Asperagus aspera & Asparagaceae & $\mathrm{x}$ & & $\sqrt{ }$ \\
\hline 21. & Aspilia africana & Astraceae & $\sqrt{ }$ & & $x$ \\
\hline 22. & Balanites aegyptiaca & Balanitaceae & $\sqrt{ }$ & & $\sqrt{ }$ \\
\hline 23. & Bersama abyssinica & Melianthaceae & $x$ & & $\sqrt{ }$ \\
\hline 24. & Cadaba farinose & Capparidaceae & $\sqrt{ }$ & & $x$ \\
\hline 25. & Caesalpinia decapetala & Fabaceae & $\sqrt{ }$ & & $\sqrt{ }$ \\
\hline 26. & Calpurnia aurea & Fabaceae & $\sqrt{ }$ & & $\sqrt{ }$ \\
\hline 27. & Capparis spinosa & Capparisdaceae & $\sqrt{ }$ & & $x$ \\
\hline 28. & Capparis tomentosa & Capparaceae & $\sqrt{ }$ & & $\sqrt{ }$ \\
\hline
\end{tabular}




\begin{tabular}{|c|c|c|c|c|}
\hline 29. & Carissa edulis & Apocynaceae & $\sqrt{ }$ & $\mathrm{x}$ \\
\hline 30. & Celtis africana & Ulmaceae & $\sqrt{ }$ & $\sqrt{ }$ \\
\hline 31. & Celtis gomphophylla & Ulmaceae & $\sqrt{ }$ & $\sqrt{ }$ \\
\hline 32. & Cirsium spp. & Asteraceae & $\sqrt{ }$ & $\mathrm{X}$ \\
\hline 33. & Cissampelos mucronata & Menispermaceae & $\mathrm{X}$ & $\sqrt{ }$ \\
\hline 34. & Cissus aphylla & Vitaceae & $\sqrt{ }$ & $\mathrm{x}$ \\
\hline 35. & Cissus.cactiformis & Vitaceae & $\sqrt{ }$ & $\mathrm{x}$ \\
\hline 36. & Clausena.anisata & Rutaceae & $\sqrt{ }$ & $\mathrm{X}$ \\
\hline 37. & Clematis.hirsute & Ranunculaceae & $\sqrt{ }$ & $\mathrm{X}$ \\
\hline 38. & Clematis.longicauda & Ranunculaceae & $\sqrt{ }$ & $\mathrm{X}$ \\
\hline 39. & Clutia.abyssinica. & Euphorbiaceae & $\sqrt{ }$ & $\sqrt{ }$ \\
\hline 40. & Colocasia esculenta. & Araceae & $\sqrt{ }$ & $\mathrm{x}$ \\
\hline 41. & Combretum collinum & Combretaceae & $\mathrm{X}$ & $\sqrt{ }$ \\
\hline 42. & Combretum molle & Combretaceae & $\sqrt{ }$ & $\sqrt{ }$ \\
\hline 43. & Commelina benghalensis & Commelinaceae & $\sqrt{ }$ & $\mathrm{x}$ \\
\hline 44. & Cordia africana & Boraginiaceae & $\sqrt{ }$ & $\mathrm{X}$ \\
\hline 45. & Cordia monoica & Boraginaceae & $\sqrt{ }$ & $\mathrm{x}$ \\
\hline 46. & Croton macrostachyus. & Euphorbiaceae & $\sqrt{ }$ & $\mathrm{X}$ \\
\hline 47. & Cucumis ficifolius & Cucurbitaceae & $\sqrt{ }$ & $\mathrm{x}$ \\
\hline 48. & Cynodon dactylon & Poaceae & $\sqrt{ }$ & $x$ \\
\hline 49. & Datura stramonium & Solanaceae & $\sqrt{ }$ & $\mathrm{x}$ \\
\hline 50. & Desmodium repandum & Fabaceae & $\sqrt{ }$ & $\mathrm{x}$ \\
\hline 51. & Dichrostachys cinrea & Fabaceae & $\sqrt{ }$ & $\sqrt{ }$ \\
\hline 52. & Dicliptera maculate & Acanthaceae & $\sqrt{ }$ & $\sqrt{ }$ \\
\hline 53. & Dodonaea angustifolia & Sapindaceae & $\sqrt{ }$ & $\mathrm{x}$ \\
\hline 54. & Dombeya torrida & Sterculiaceae & $\sqrt{ }$ & $\mathrm{x}$ \\
\hline 55. & Embelia schimperi & Myrsinaceae & $\mathrm{X}$ & $\sqrt{ }$ \\
\hline 56. & Erythrina brucei & Fabaceae & $\sqrt{ }$ & $\mathrm{x}$ \\
\hline 57. & Eucalyptus camaldulensis & Myrsinaceae & $\sqrt{ }$ & $\sqrt{ }$ \\
\hline
\end{tabular}




\begin{tabular}{|c|c|c|c|c|}
\hline 58. & Euphorbia abyssinica & Euphorbiaceae & $\sqrt{ }$ & $\sqrt{ }$ \\
\hline 59. & Euphorbia pulcherrima & Euphorbiaceae & $x$ & $\sqrt{ }$ \\
\hline 60. & Euphorbia tirucalli & Euphorbiaceae & $\sqrt{ }$ & $\sqrt{ }$ \\
\hline 62. & Ficus thonningii & Moraceae & $\mathrm{X}$ & $\sqrt{ }$ \\
\hline 63. & Ficus vasta & Moraceae & $\sqrt{ }$ & $\mathrm{x}$ \\
\hline 64. & Galiniera saxifrage & Rubiaceae & $\mathrm{X}$ & $\sqrt{ }$ \\
\hline 65. & Gardenia ternifolia & Rubiaceae & $x$ & $\sqrt{ }$ \\
\hline 66. & Gravilla robusta. & Proteaceae & $\sqrt{ }$ & $\mathrm{X}$ \\
\hline 67. & Grewia bicolor & Tiliaceae & $\sqrt{ }$ & $\sqrt{ }$ \\
\hline 68. & Hibiscus acetosella. & Malvaceae & $\sqrt{ }$ & $\mathrm{X}$ \\
\hline 69. & Hibiscus aethiopicus & Malvaceae & $\sqrt{ }$ & $\mathrm{X}$ \\
\hline 70. & Hibiscus.macranthus & Malvaceae & $\mathrm{x}$ & $\sqrt{ }$ \\
\hline 71. & Hibiscus Spp. & Malvaceae & $\sqrt{ }$ & $\mathrm{X}$ \\
\hline 72. & Hippocratea africana & Celastraceae & $\sqrt{ }$ & $\mathrm{X}$ \\
\hline 73. & Hypericum quartinianum & Guttiferae & $\sqrt{ }$ & $\mathrm{X}$ \\
\hline 74. & Hypoestes forskaolii & Acanthaceae & $\mathrm{x}$ & $\sqrt{ }$ \\
\hline 75. & Ipomoea batatas & Convolvulaceae & $\sqrt{ }$ & $x$ \\
\hline 76. & Ipomoea purpurea & Convolvulaceae & $\sqrt{ }$ & $x$ \\
\hline 77. & Jacaranda Memosifolia & Bignoniaceae & $\sqrt{ }$ & $\mathrm{x}$ \\
\hline 78. & Kalanchoe petitiana & Crassulaceae & $\sqrt{ }$ & $\mathrm{X}$ \\
\hline 79. & Lantana camara & Verbenaceae & $\sqrt{ }$ & $\sqrt{ }$ \\
\hline 80. & Maesa lanceolata & Myrsinaceae & $\sqrt{ }$ & $\sqrt{ }$ \\
\hline 81. & Maytenus addat & Celastraceae & $\sqrt{ }$ & $\mathrm{X}$ \\
\hline 82. & Maytenus arbutifolia & Celastraceae & $\sqrt{ }$ & $\sqrt{ }$ \\
\hline 83. & Maytenus spp & Celastraceae & $\sqrt{ }$ & $\mathrm{X}$ \\
\hline 84. & Melinis repens & Poaceae & $x$ & $\sqrt{ }$ \\
\hline 85. & Microglossa pyrifolia & Asteraceae & $\sqrt{ }$ & $\sqrt{ }$ \\
\hline 86. & Momordica foetida & Cucurbitaceae & $x$ & $\sqrt{ }$ \\
\hline 87. & Myrsine africana & Myrsinaceae & $\sqrt{ }$ & $\sqrt{ }$ \\
\hline
\end{tabular}




\begin{tabular}{|c|c|c|c|c|}
\hline 88. & Mytenus africana. & Celastraceae & $\sqrt{ }$ & $\mathrm{X}$ \\
\hline 89. & Ocimum lamiifolium & Lamiaceae & $\sqrt{ }$ & $\sqrt{ }$ \\
\hline 90. & Ocimum spp. & Lamiaceae & $\sqrt{ }$ & $\mathrm{X}$ \\
\hline 91. & Olea spp & Oleaceae & $\mathrm{x}$ & $\sqrt{ }$ \\
\hline 92. & Osyris quadripartita & Santalaceae & $\sqrt{ }$ & $\sqrt{ }$ \\
\hline 93. & PParthenium hysterophorus & Astraceae & $\sqrt{ }$ & $\sqrt{ }$ \\
\hline 94. & Prunus africana & Rosaceae & $\sqrt{ }$ & $\mathrm{X}$ \\
\hline 95. & Psidium guajava & Myrtaceae & $\sqrt{ }$ & $\mathrm{X}$ \\
\hline 96. & Rhus natalensis & Anacardiaceae & $\sqrt{ }$ & $\mathrm{X}$ \\
\hline 97. & Rhus vulgaris & Anacardiaceae & $\sqrt{ }$ & $\mathrm{X}$ \\
\hline 98. & Ricinus communis & Euphorbiaceae & $\sqrt{ }$ & $\mathrm{X}$ \\
\hline 99. & Roza abysinica. & Rosaceae & $\sqrt{ }$ & $\mathrm{X}$ \\
\hline 100. & Rumex abyssinicus & Polygonaceae & $\sqrt{ }$ & $\mathrm{X}$ \\
\hline 101. & Rumex.nervosus. & Polygonaceae & $\sqrt{ }$ & $\mathrm{X}$ \\
\hline 102. & Schrebera alata. & Oleaceae & $\mathrm{x}$ & $\sqrt{ }$ \\
\hline 103. & Senna didymobotrya & Fabaceae & $\sqrt{ }$ & $\sqrt{ }$ \\
\hline 104. & Senna ocidentalis. & Fabaceae & $\sqrt{ }$ & $\sqrt{ }$ \\
\hline 105. & Senna Spp. & Fabaceae & $\sqrt{ }$ & $x$ \\
\hline 106. & Senra incana & Malvaceae & $\sqrt{ }$ & $\sqrt{ }$ \\
\hline 107. & Sida rhombifolia & Malvaceae & $\sqrt{ }$ & $\sqrt{ }$ \\
\hline 108. & Sida schimperiana & Malvaceae & $\sqrt{ }$ & $\sqrt{ }$ \\
\hline 109. & Solanum incanum & Solanaceae & $\sqrt{ }$ & $\sqrt{ }$ \\
\hline 110. & Stephania abyssinica & Menispermaceae & $\sqrt{ }$ & $\mathrm{X}$ \\
\hline 111. & Syzygium guineense & Myrtaceae & $\sqrt{ }$ & $\sqrt{ }$ \\
\hline 112. & Teclea nobilis & Rutaceae & $\sqrt{ }$ & $\mathrm{x}$ \\
\hline 113. & Terminalia laxiflora & Combretaceae & $\sqrt{ }$ & $\mathrm{X}$ \\
\hline 114. & Trigonella Spp. & Fabaceae & $\sqrt{ }$ & $\sqrt{ }$ \\
\hline 115. & Verbascum sinaiticum & Scrophulariaceae & $\sqrt{ }$ & $\mathrm{X}$ \\
\hline 116 & Vernonia Spp. & Asteraceae & $\sqrt{ }$ & $\mathrm{x}$ \\
\hline
\end{tabular}




\begin{tabular}{|lllcl|}
117 & Vernonia amalgadina. & Asteraceae & $\sqrt{ }$ & X \\
118 & Vernonia auriculifera & Asteraceae & $\sqrt{ }$ & X \\
119 & Vernonia schimperi. & Asteraceae & $\sqrt{ }$ & X \\
120 & Withania somnifera & Solanaceae & X & X \\
121. & Xanthium spinosum & Asteraceae & $\sqrt{ }$ & X \\
122. & Xanthium strumarium & Asteraceae & $\sqrt{ }$ & X \\
123. & Ziziphus abyssinica & Rhamnaceae & $\sqrt{ }$ & $\sqrt{ }$ \\
124. & Ziziphus spina.christi. & Rhamnaceae & $\sqrt{ }$ & $\mathrm{X}$ \\
\hline 125. & Zizipus Spp. & Rhamnaceae & $\sqrt{ }$ & \\
\hline
\end{tabular}

\section{Discussion}

Lantana camara affected severely the diversity and composition of invaded flora in the study area. The result of this study indicated that the number plant species, Simpson_1-D index of dominance, Shannon_H index diversity, Margalef's index of species richness, and evenness index were reduced significantly in the Lantana camara invaded areas as compared to control. The report of the study by Ghisalberti, (2000), Sharma et al.(2005), French et al. (2009) and Nel (2015) indicated that the impacts of Lantna camara on native biodiversity is highly marked because of the species' invasive characteristics, such as rapid vegetative growth, aggressive competitive ability, high seed production, and proliferation throughout the year in ideal environmental conditions. In addition, there are allelochemicals present almost in all parts of the plant (Choyal and Sharma,2011).

Besides, the higher value of index of dominance in the invaded areas would be predicted that the communities were homogenous in nature and dominated by a single whereas the lower value of index of dominance for non-invaded floral communities would be indicated that the heterogeneous nature of these communities and the communities were not dominated by a single or few species. Moreover, a low value of the Simpson diversity index in invaded study sites also suggests an area was dominated by a few species, homogenous nature of these communities. For instance, in Mechisho community forest (with the lowest value of Simpson diversity index), only the invader was dominated the community. It could be the result of the high invasion of Lantana camara. The study by Melkamu Kifetew (2005), Wambua (2010), Nel (2015) and Firew Bekele (2018) indicated the various impacts of Latana camara on the diversity of plants species.

On the other hand, if there are more successful species with no species completely dominating the area, the value of the Simpson diversity index is high (the control) (Barrantes and Sandoval, 2009). The communities were showing more heterogeneity in the un-invaded study areas. A high diversity index of Waleme community forest suggests that the area was not dominated by one or two species rather by large number of species which result a more stable ecosystem as reported by Chatterjee (2015) on the 
impact of Lantana camara on the diversity of plant species. Waleme area community forest was the least affected by the invasion of Lantana camara. This might be due to the soil or other environmental factor limited the expansion of Lantana camara when compared to other study areas.

The result of the study by Dobhal et al. (2010) also indicated that Lantana camara is a serious threat to all major native shrubs growing along Nayar river of Pauri Garhwal, in Uttarakhand State, Himalaya, Northern India which were affected by speedy blowout and distinctive capacity to seize empty niche. In addition the study by Lwando (2009) also indicated that Lantana camara has predominant impact on Plant Diversity in Zambia. Generally, Shannon_H index diversity decreased with the corresponding increase in the Percentage of Lantana camara. The result of study by Hejda et al. (2009) also confirmed the impact of IAPSs on the species richness, diversity and composition of invaded communities.

As the coverage of Lantana camara increased, Species Evenness per study site decreased. Evenness (E) has values between 0 and 1.0, where 1.0 represents a situation in which all species are equally abundant (Nagendra, 2002). The result of this study also confirmed that regression equation and Pearson correlation coefficient indicated the existence of strong negative linear relationship between diversity of plant species and number of Lantana camara. It indicated that there was a justification for the existence of great impact of number of Lantana camara on diversity of plant species. This study also indicated that plant species diversity in Lantana camara invaded areas was low. The tests of association (t-test) indicated that there was significant variation in plant species diversity between the invaded and noninvaded plant community in the study areas ( $p$-value $=0.000069$ which is $<0.05$ ). The study by Morton (1994) also indicated numerous impacts of Lantana camara invasion on diversity of plant species.

A post-ANOVA test; Tukey's Honest Significant Difference (H.S.D) at $95 \%$ means was used to separate the means Pallant (2011). In this study ANOVA and then post-hoc tests/ Tukey HSD was conducted to find out which pair of independent variables (number of Lantana camara) are significantly different that had significant impact on diversity of plant species (dependent variables) on invaded plant communities of the study areas. Hence, the majority of pair of independent variables in this study was significantly different.

Furthermore, in this investigation PCA (Ordination) was conducted in order to place the points such that points that are nearby together match to sites that are comparable in species composition and points that are distant apart relate to sites that are unrelated in species composition (Chahouki,2012). The plots for both invaded and non-invaded sites, the region from the origin for a row (site/plots) implies how much the point differs from the average and the area from the origin for a column (species, variable) implies how much the point increases to that direction. Accordingly, PCA was performed in invaded and noninvaded floral communities in three selected Kebeles to know the correlation between plots and the plant species. If two plots close to each other in ordination they have similar plant species and if two plots have analogous plant species, they have related environment. Two sites extreme away from each other in ordination have unrelated plant species, and perhaps have different environment (Paliy and Shankar, 2016, Oulu, 2016). 
The scores acquired from a PCA for species and sites can be used to prepare a bi-plot. Consequently, PCA displayed that the species distribution scheme in association with the specific sites in the invaded and non- invaded study areas. Regarding to the non-invaded floral communities, the first two principal components together accounted for $31.6 \%$ of the total variance in data set following by the third principle component. This means that the first principal component is superior for demonstrating the distinction of the diversity of plant communities in the three study Kebeles following by the second and third principal components. Moreover, the PCA biplot axis, indicated the isolation of the common plant species including Solanum incanum, Datura stramonium, Amaranthus caudatus, Ageratum conyzoides, Ziziphus abyssinica, Osyris quadripartita, Acacia abyssinica, Achyranthes spp., Stephania abyssinica and Acacia saligna indicating the existence of various plant species which might be due to the suitable environmental condition in non-invaded study sites.

Concerning to the invaded floral communities, majority of the plots were close together which might be revealed that those sites/plots were similar in species diversity and composition. This might be resulted that the reducing diversity levels with increasing cover of the Lantana camara (Wekhanya, 2016, Shaheen et al., 2019). On the other hand, plots 52, 53 and 55 were far apart to each other's and from the other plots which might be indicated that those plots were unrelated in species diversity and composition.

The diversity and number of family declined considerably in the Lantana camara invaded area (Vardien et al., 2012, Gantayet et al., 2014). Fabaceae, Asteraceae, Malvaceae, Euphorbiaceae and Celastraceae contributed most of species (40.89\%) to the total flora in non-invaded study sites. Fabaceae was the dominant family in both invaded and non-invaded study areas. This might be due to the suitable environmental condition to the species in the family and large number of species in this family.

\section{Conclusion}

Lantana camara categorized as the dominant IAPS in selected study Kebeles of the study areas that reduced species diversity and composition of various plant species in invaded communities. Information on impact of IAPSs on diversity and composition of any plant community is very important for their management. This invasive species has negative impacts on the indigenous plant and its impacts are projected to increase with time. The problem is however aggravated in the majority of terrestrial habitat. Therefore, a management and control strategy for Lantana camara and other IAPSs needs to be instituted. Finally, Lantana camara has already been established in the study areas and other parts of the country; therefore, further research is required to ascertain the best control and management strategy.

\section{Declarations}

\section{Acknowledgments}

The authors are Grateful to Ethiopian Biodiversity Institute (EBI) for financial support during the field work. 
Authors' contributions: Both authors contributed to the study formation and design. Material preparation, data collection and analysis were performed by the first author. The first draft of the manuscript was written by the first author. The second author supervised the entire work of this research and edited the subsequent versions of the manuscript. Finally, the second author read and approved the final manuscript.

\section{Funding}

This study was supported by Ethiopian Biodiversity Institute (EBI) in the course of the field work.

\section{Availability of data and material}

The data analyzed during the current study are available from the corresponding author on reasonable request

\section{Conflicts of Interest}

The authors declare no conflict of interest.

\section{Consent for publication}

Both authors declare that neither the article nor portions of it have been previously published elsewhere; not under consideration for publication in another journal and both authors also consent to the publication of the manuscript in journal of Biological Invasions.

\section{References}

Abiyu Enyew, and Raja, N. (2015). Allelopathic Effect of Lantana camara L. Leaf Powder on Germination and Growth Behaviour of Maize, Zea mays Linn. and Wheat, Triticum turgidum Linn. Cultivars. Asi. J. of Agri. Sci., 7(1), 4-10.

Aravind,N. A., Rao,D., Ganeshaiah, K. N.,Shaanker,R.U., and Poulsen,J. G. (2010). Impact of the invasive plant, Lantana camara, on bird assemblages at Malé Mahadeshwara Reserve Forest, South India: Trop.Ecol. 51 (25), 325-338.

Barrantes,G. and Sandoval, L. (2009). Conceptual and statistical problems associated with the use of diversity indices in ecology: Int. J. Trop. Biol., 57 (3), 451-460.

Biodiversity Conservation, Environmental Management and Rural Development (BIOCEM-RD) (2016) Ltd. Study to assess the impacts of invasive alien species in natural forests, agro-ecosystems, lakes and wetland ecosystems in Rwanda and develop their management plans. Final report.

Chahouki,M.A.Z. (2012). Classification and Ordination Methods as a Tool for Analyzing of Plant Communities; the world's leading publisher of Open Access books Built by scientists, for scientists; 
licensee In Tech. (http://creativecommons.org/licenses.3.0). Iran,;1-35.

Chatterjee, R. (2015). Impact of Lantana camara in the Indian society: Int. J.of Envi.; 4(2), 348-354.

Choyal,R. and Sharma,S.K. (2011). Evaluation of Allelopathic effects of Lantana camara (Linn) on regeneration of Pogonatum aloides in culture media: As. J. of Pla. Sci. and Rese.,1 (3),41-48.

Dobhal, P.K., Kohli, R.K.,and Batish,D.R.(2010). Evaluation of the impact of Lantana camara L. invasion, on four major woody shrubs, along Nayar river of Pauri Garhwal, in Uttarakhand Himalaya: Int. J. of Biodiv. and Cons.;2(7), 155-161.

Dogra,K.S, Kohli, R. K., Sood, S. K., and Dobhal, P.K. (2009). Impact of Ageratum conyzoides L. on the diversity and composition of vegetation in the Shivalik hills of Himachal Pradesh (Northwestern Himalaya), India, Int. J.of Bio. and Con.,1(4), 135-145.

Firew Bekele (2018). Invasive Lantana camaraL. Shrub in Ethiopia: Ecology, Threat, and Suggested Management Strategies. J. of .Agric. Sci, 10 (7), 184-195.

French, G, B.K., Turner,P.J. and Downey, P.O. (2009). Impact threshold for an alien plant invader, Lantana camara L., on native plant communities. Bio. Cons., 142: 2631-2641.

Gantayet, P.K., Adhikary, S.P., Lenka, K.C., and Padhy,B. (2014). Allelopathic Impact of Lantana Camara on Vegetative Growth and Yield Components of Green Gram (Phaseolus radiatus) ;Int.J.Curr.Microbiol.App.Sci.;3(7),327-335

Genovesi and Shine.C.(2004). European strategy on IAS Convention on the Conservation of European Wildlife and Habitats (Bern Convention) Nature and environment, No. 137 Council of Europe Publishing French edition: ISBN 92-871-5487-2. Council of Europe Publishing, F-67075.

Ghisalberti, E.L.(2000). Review: Lantana camara L. (Verbenaceae). Fitoterapia. Elsevier Science., 71,467486.

Global Environment Facility (GEF) (2003). Removing barriers to invasive plant management in Africa. Project document. Glosa (Environmental Facility, United Nations Environmental Program).

Habtamu Kefelegn (2015). Invasive Alien Weed Species Impacts on Biodiversity and Socio-Economic Aspect in Ethiopia: A Review. Int. J. of .Sci.and Rese.. 4(10), 2179- 2185.

Hejda, M. Pysek,P. and Jarosík,V. (2009). Impact of invasive plants on the species richness, diversity and composition of invaded communities :British Ecological Society, J. of Ecol.,97,393-403

International Union for Conservation of Nature (IUCN) (2009). The Invasive Species Context: general principles. Workshop on biofuel production and invasive species, Wasaa, Nairobi, Kenya. 
Kumar, R., Katiyar, R., Kumar, S., Kumar,T., and Singh,V.(2016) .Lantana camara: an alien weed, its impact on animal health and strategies to control : J. of. Exntal. Bio. and Agri. Sci.,4(3S) 321_337.

Lisanework Nigatu, Asresie Hassen, Sharma, J., and Adkins, S.W. (2010). Impact of Parthenium hysterophorus on grazing land communities in north-eastern Ethiopia, Weed Bio. and Manag., J. comp.10, 143-152.

Lwando, C. (2009). Effect of Lantana camara on Plant Diversity in Zambia :Russell E. Train Fellows; EFN(Education For Nature) Professional Development Grants; New Fellowship Competition.;1(1),1-5.

Melkamu Kifetew (2005) .Impact Assessment on an Invasive Species, Lantana camara on Indigenous Species Composition and Socio-economic Environment around Adama and Bishofitu Areas, Ethiopia: A Thesis Submitted to the School of Graduate Studies of Addis Ababa University in Partial Fulfillment of Master's Degree in Environmental Science, Addis Ababa.

Morton, J.F. (1994).Lantana, or a Red Sage (Lantana camera L., (Verbeneceae), Notorious weed and Popular Garden Flower; Some Cases of Poisoning in Florida. J. of .Econ. Bot:;, 48,259-270.

Nagendra. H. (2002). Opposite trends in response for the Shannon and Simpson Indices of Landscape diversity., Appl. Geog..:,22, 175-186.

Nel,L.(2015). Effects of a highly invasive plant (Lantana camara) on an agricultural flower visitation network: Thesis presented in fulfillment of the requirements for the degree of Master of Science (Conservation Ecology) in the Faculty of AgriSciences (Department of Conservation Ecology and Entomology),Stellenbosch University, the Western Cape province of South Africa.

Oulu,J.O.(2016). Multivariate Analysis in Ecology; Multivariate Analysis and Ordination http://cc.oulu._ jarioksa/ (Oulu).,1-47.

Paini, D.R., Sheppard, A.W., Cook, D.C., De Barro, P.J., Worner, S.P., Thomas, M.B. (2016). Global threat to agriculture from invasive species. Pro. National Academy of Sciences. 113 (27), 7575-9.

Paliy,O. and Shankar,V. (2016). Application of multivariate statistical techniques in microbial ecology; HHS Public Access; Mol Ecol., 25(5), 1032-1057.

Pallant,J. (2011).SPSS Survival Manual a step by step guide to data analysis using SPSS, 4th edition Cataloguing-in-Publication, National Library of www.librariesaustralia.nla.gov.au.,Australia.148-167.

Rezene Fessehaie and Taye Tessema (2014). Alien Plant Species Invasions in Ethiopia: Challenges and Responses. Ethiopian Institute of Agricultural Research.

Sebsebe Demissew and Hedberg,I. (2006). Flora of Ethiopia and Eritrea, formatted with Ventura Publisher, Addis Ababa, Ethiopia,Volume. 5, p. 507. 
Shaheen,H., Batool,A., Gillani,S.F., Dar,M.E.I., Habib,T., Aziz,S. (2019). Diversity and Distribution of Invasive Plant Species in Suburban Vegetation of Kashmir Himalayas. Poli. J.I of .Envi.tal. Stu. 28(4),111.

Sharma,G.P., Raghubanshi,A.S., and Singh, J. S. (2005). Lantana camara invasion: An overview Review paper Blackwell Publishing Asia Pty Ltd ,Weed Bio and Manag, 5, 157-165.

Vardien, W., Richardson, D.M. , Foxcroft, L.C. , and Thompson, G.D. , Wilson, J.R.U. and Le Roux, J.J. (2012). Review: Invasion dynamics of Lantana camara L. (sensu lato) in South Africa. Sout. Afri. J. of Bot:, 81: 81-94.

Vaughan,S. (2003). Ethnicity and Power in Ethiopia. Ph.D. Thesis, University of Edinburgh, Scotland.

Wambua,J.K. (2010). The distribution, abundance and ecological impacts of invasive plant species at oldonyo sabuk national park, Kenya , A thesis submitted in partial fulfillment for the Degree of Master of science in the Biology of Conservation, University of Nairobi, School of Biological Sciences, Nairobi,.

Wekhanya, M. N. (2016). The effect of invasive species Lantana camara on soil chemistry at Ol- Donyo Sabuk National park, Kenya, A thesis submitted in partial fulfillment of the requirements for award of the degree of masters of Science (Plant Ecology) in the school of pure and applied sciences, Kenyatta University, Kenya.

Zebene Asfaw and Agren,G. I. (2007). Farmers' local knowledge and topsoil properties of agroforestry practices in Sidama, Southern Ethiopia. Agroforestry Systems, An acad. Public.:. 71 (1):35-48.

\section{Figures}




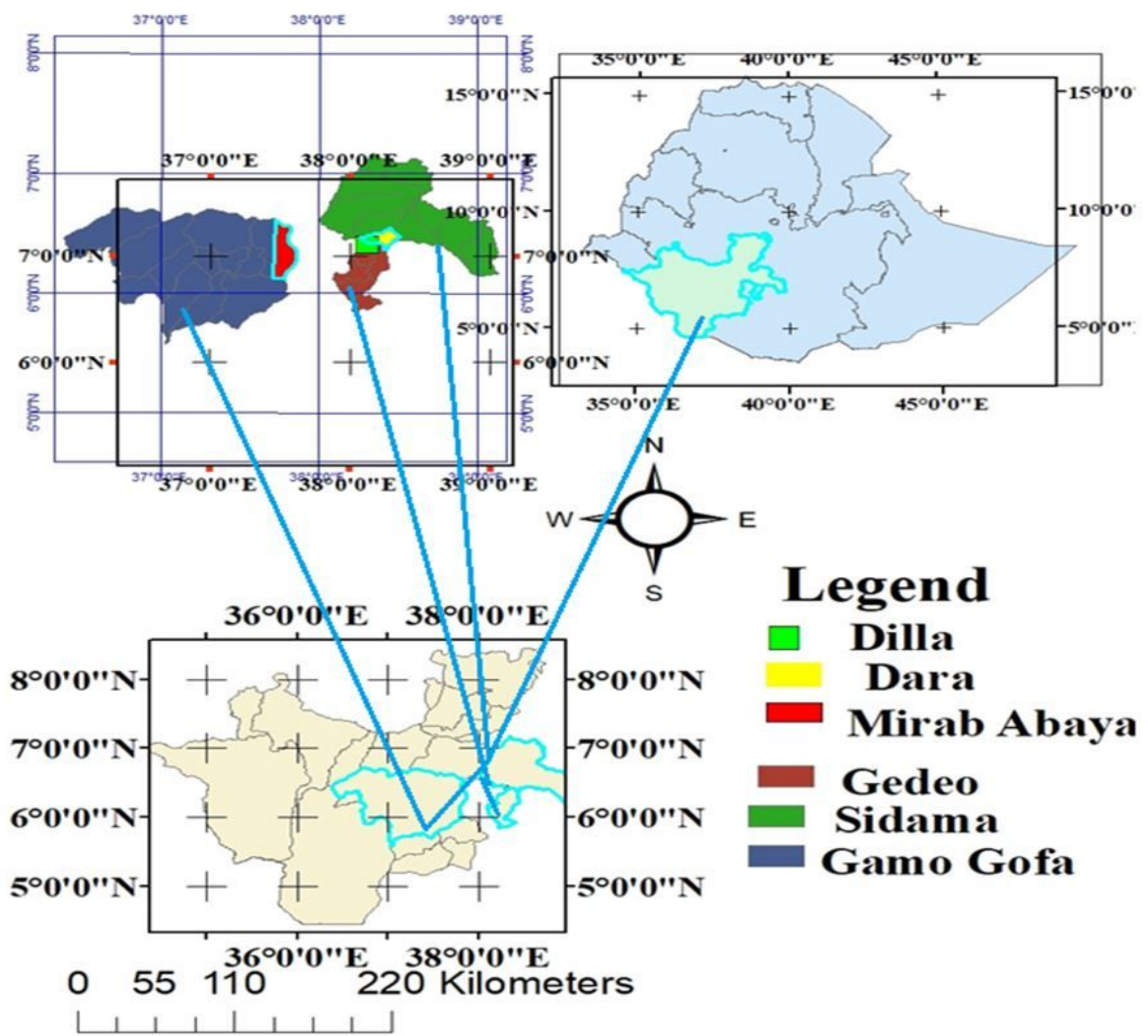

Figure 1

Administrative Map of the study area 


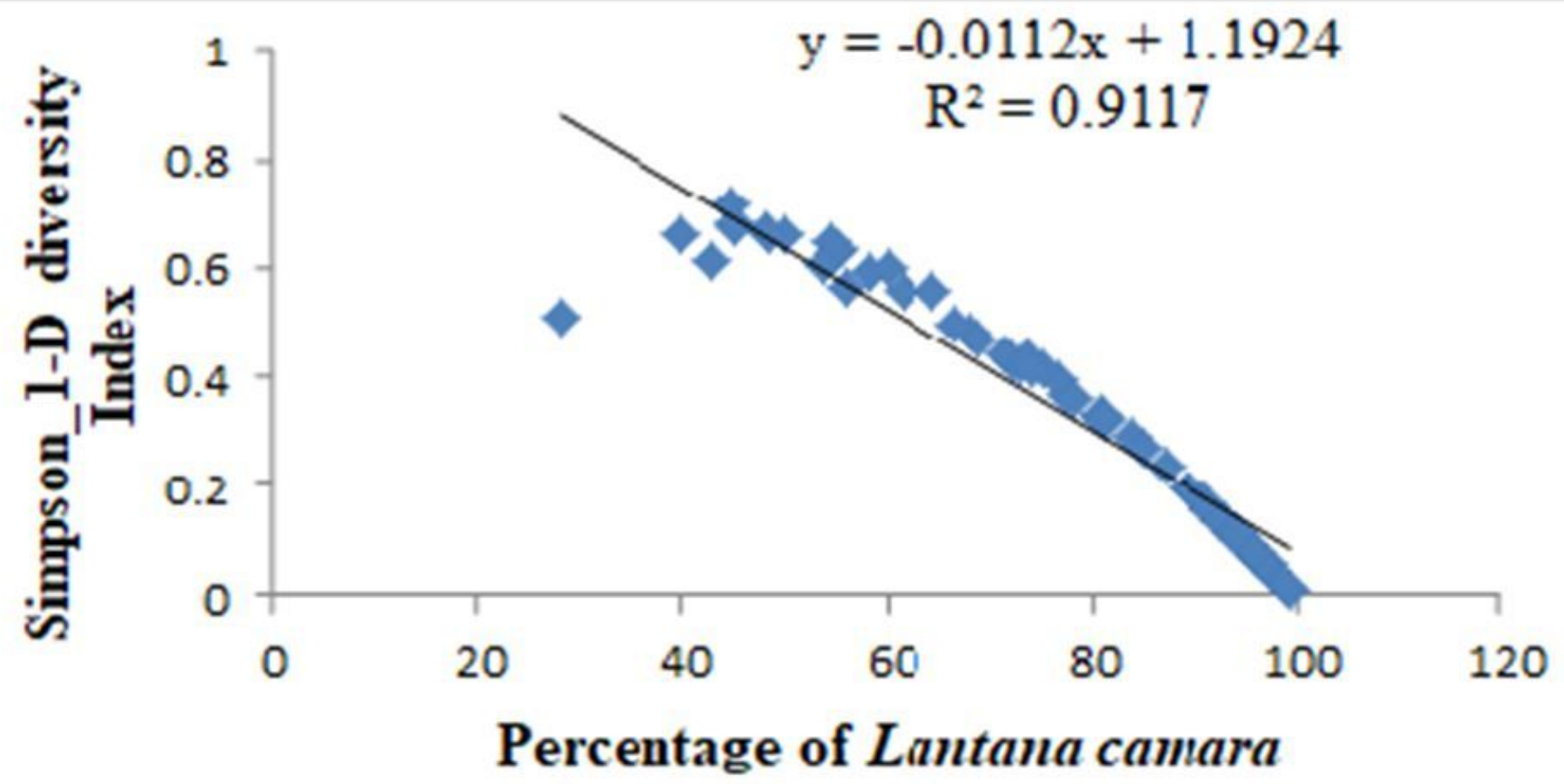

Figure 2

the Relationship between Simpson_1-D Index of Diversity and Percentage of Lantana camara per invaded quadrat $(\mathrm{R} 2=0.9117, \mathrm{p}<0.01)$.

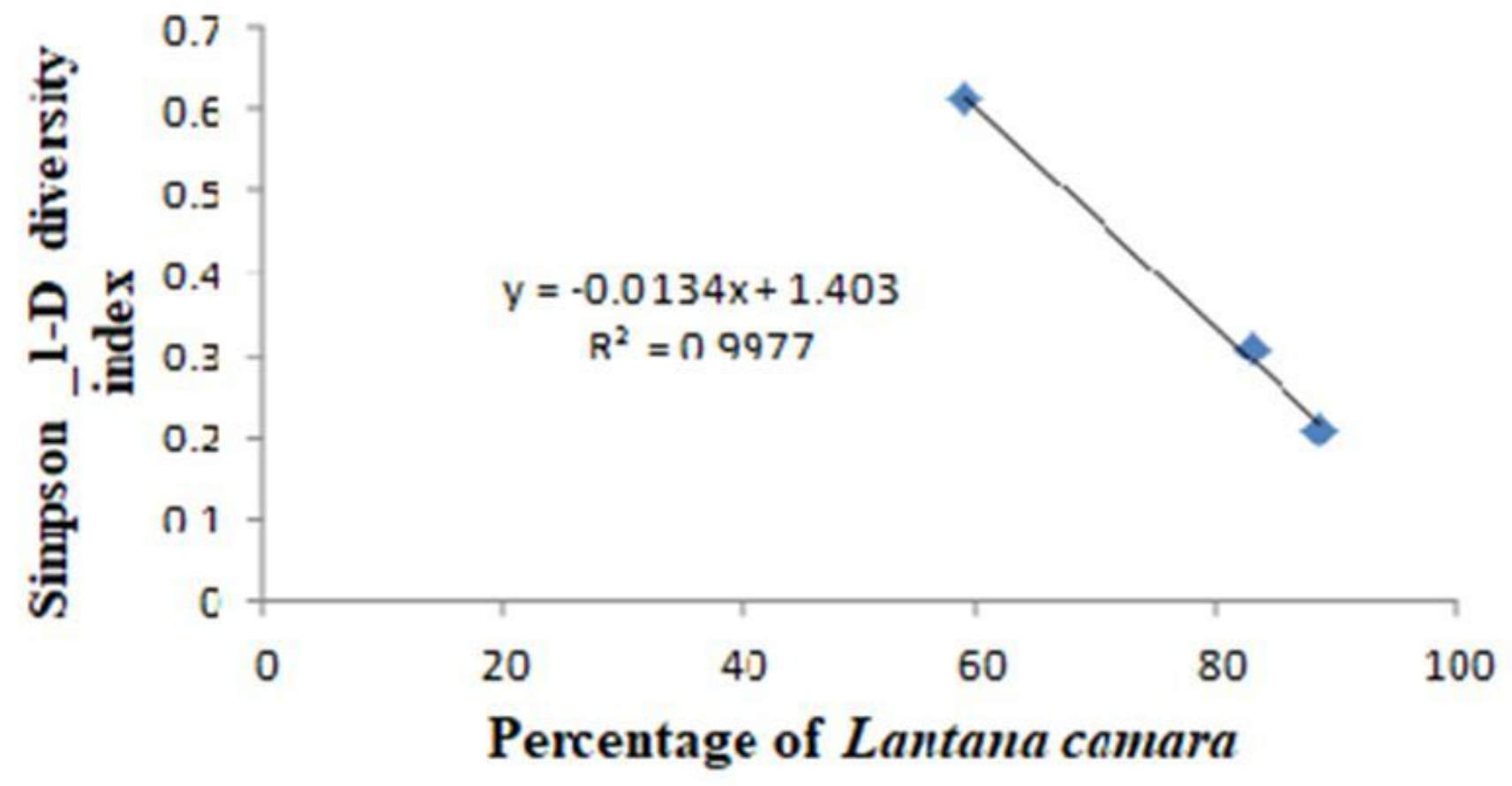

Figure 3 
the relationship between Percentage of Lantana camara and Simpson_1-D Index of Diversity per invaded study Kebele $(R 2=0.998, p<0.01)$

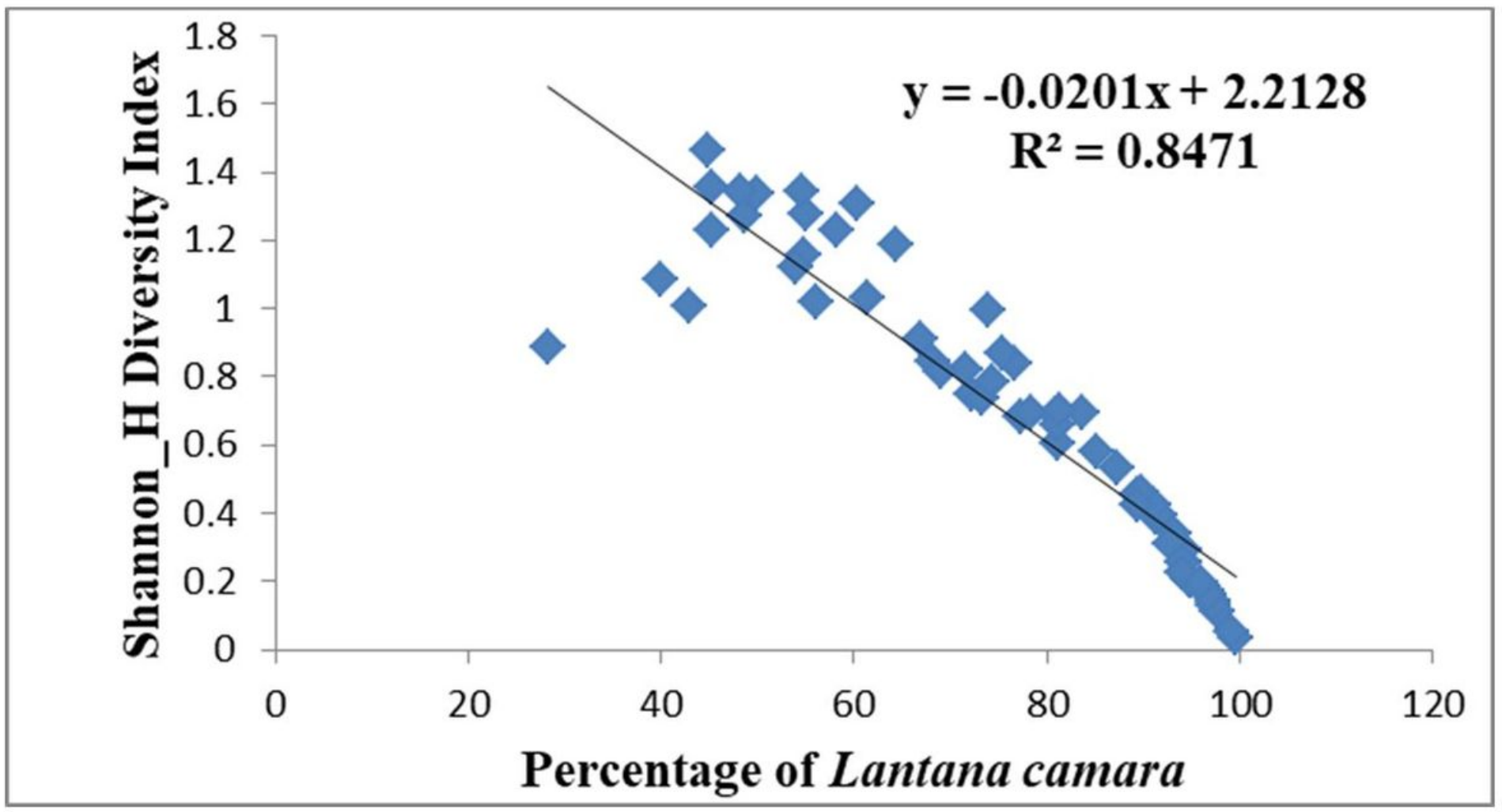

Figure 4

The relationship between Percentage of Lantana camara and Shannon_H index diversity per invaded quadrat $(R 2=0.847, p<0.01)$. 


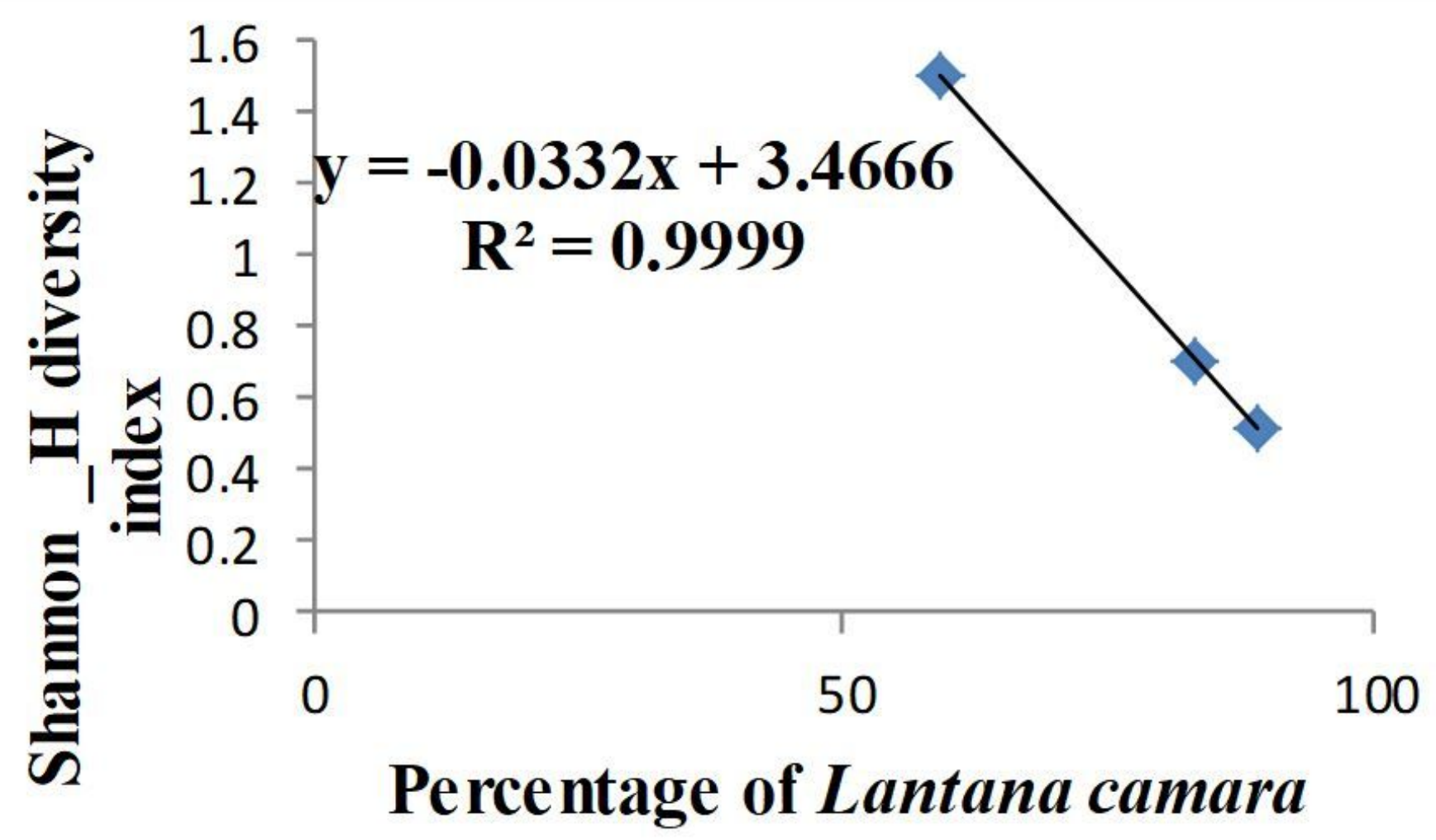

Figure 5

the relationship between Percentage of Lantana camara and Shannon_H index diversity per invaded study Kebele $(R 2=0.999, p<0.01)$. 


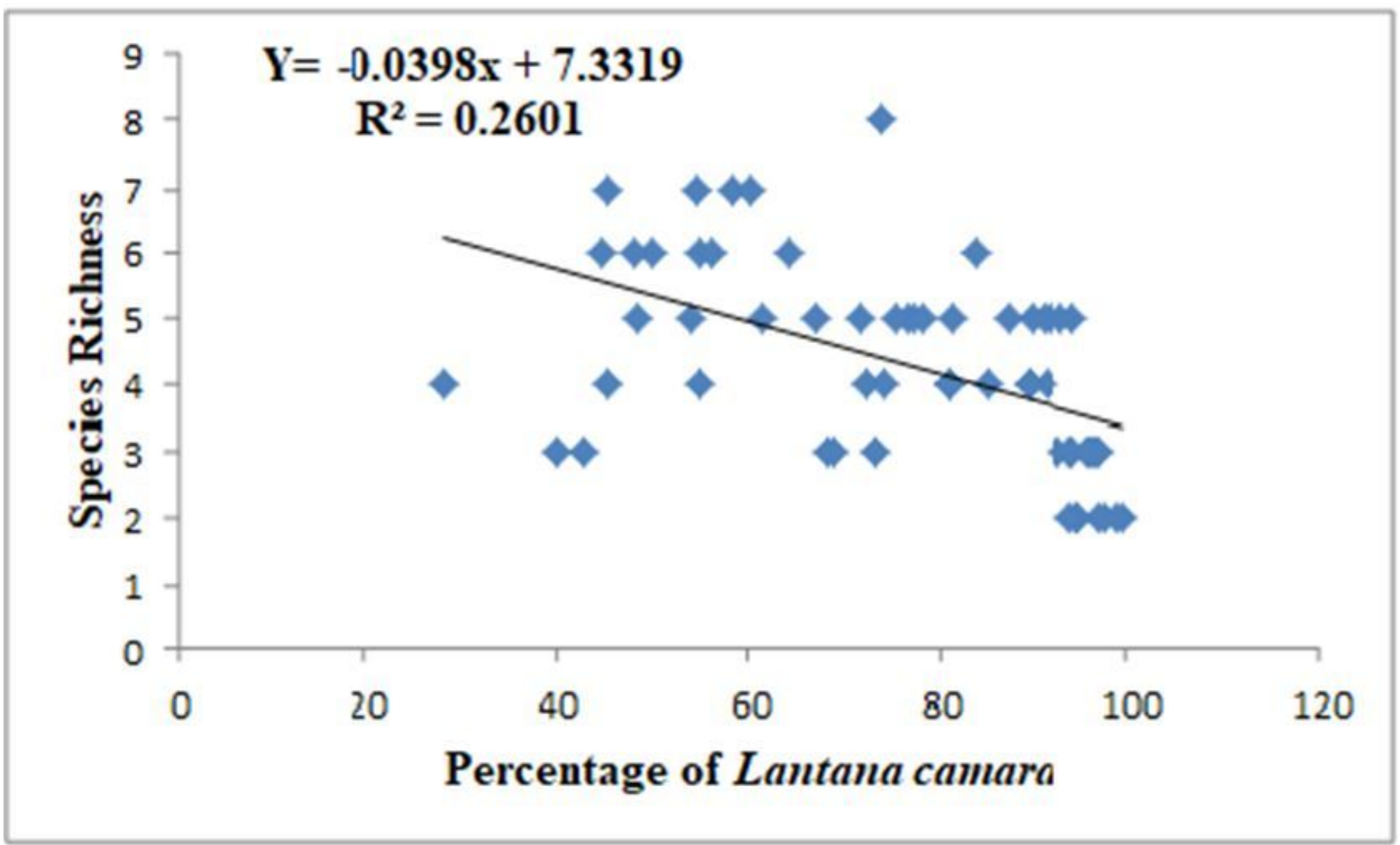

Figure 6

the relationship between Percentage of Lantana camara and Species Richness per invaded quadrat $(\mathrm{R} 2=$ $0.2601, p<0.01)$. 


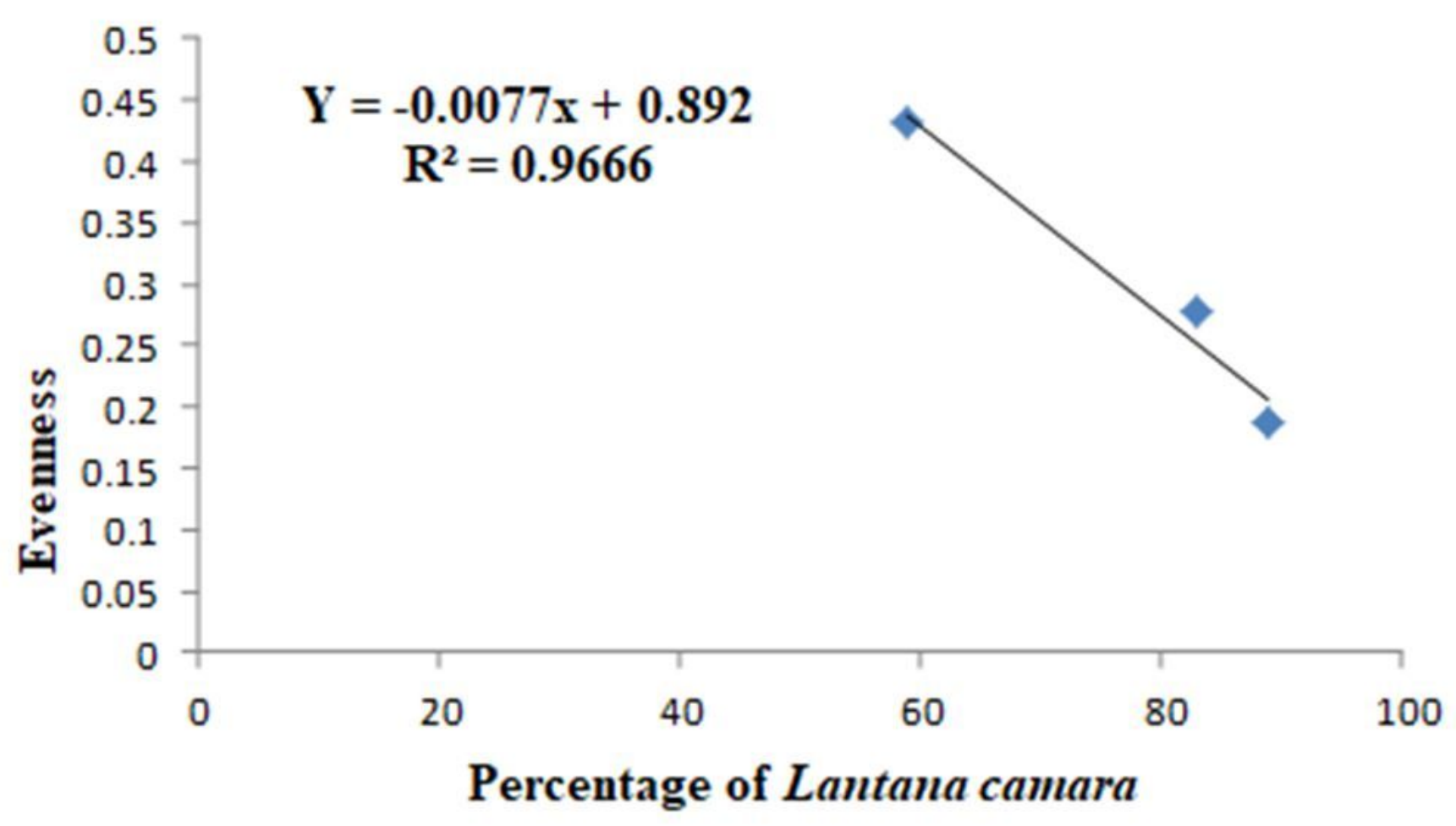

Figure 7

the relationship between Percentage of Lantana camara and Species Evenness per Study Invaded Kebele $(\mathrm{R} 2=0.967, \mathrm{p}<0.01)$.

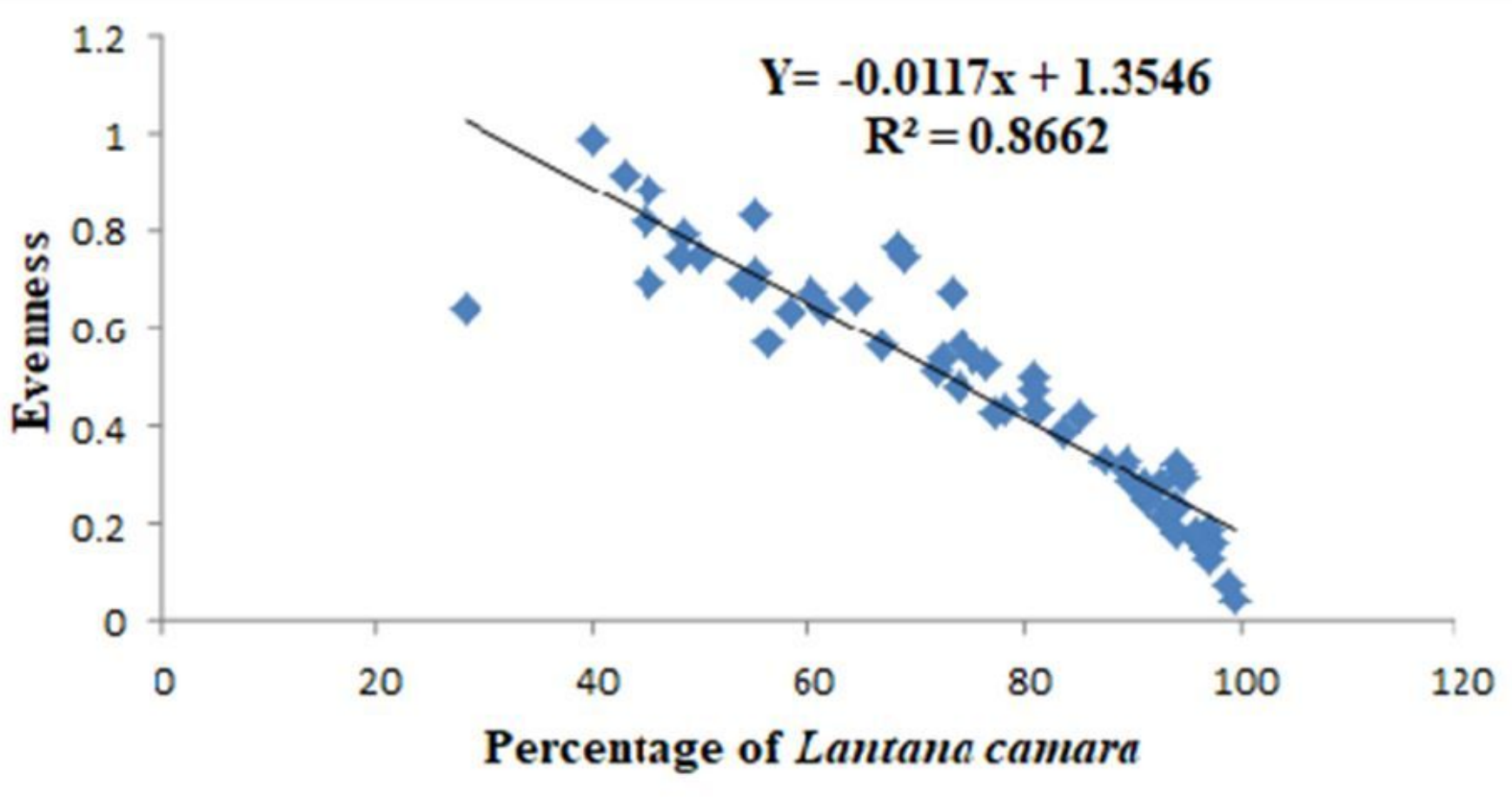


Figure 8

The relationship between Percentage (coverage) of Lantana camara and Evenness of Plants per invaded quadrat $(\mathrm{R} 2=0.8662, \mathrm{p}<0.01)$.

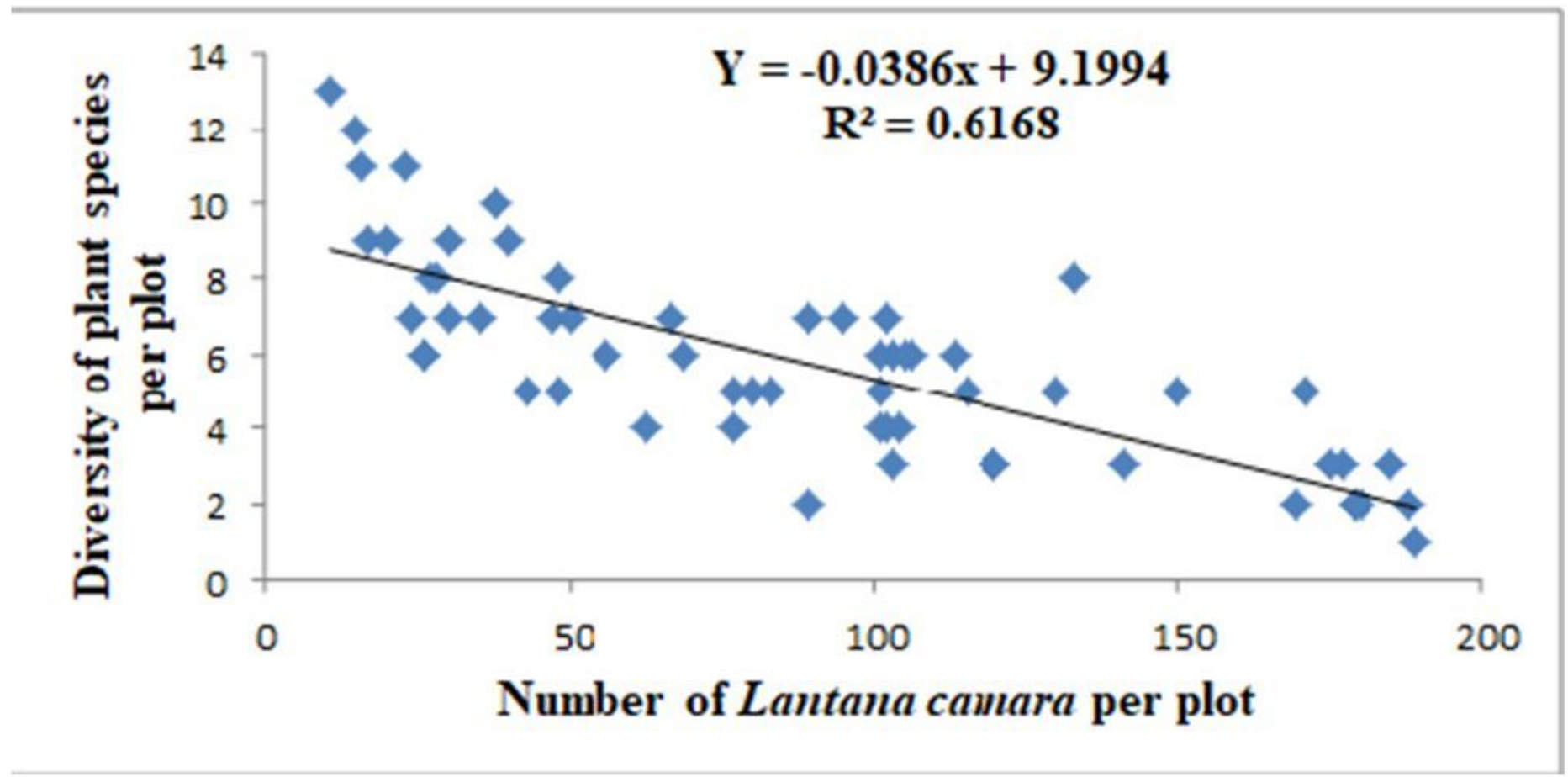

Figure 9

the relationship between diversity of plant species and number of Lantana camara per quadrat (R2 = $0.6168, p<0.01)$ 


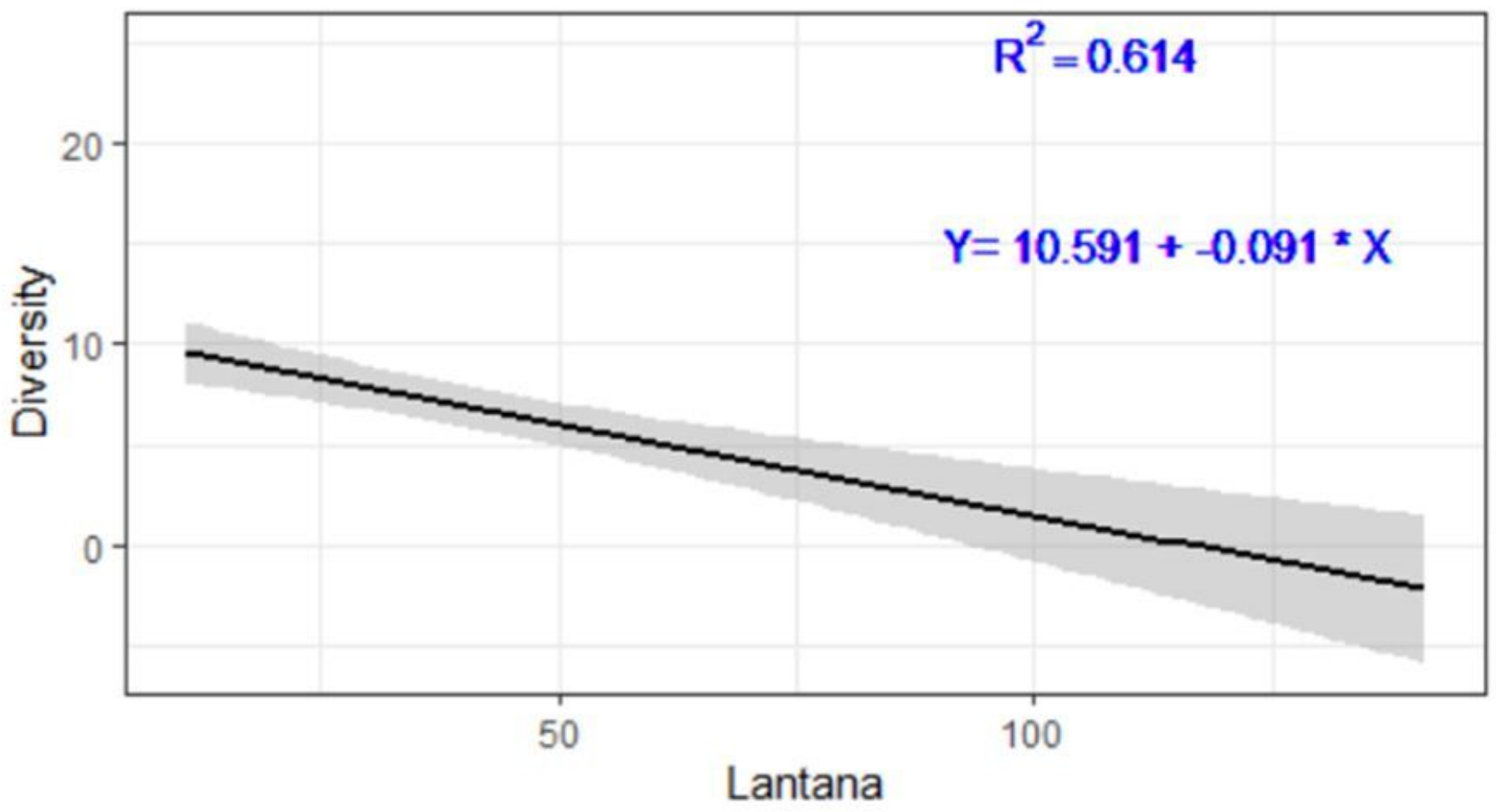

Figure 10

Diversity of Plant species $(\mathrm{Y})$ and number of Lantana camara per invaded plot $(\mathrm{X})$ ( Waleme Kebele community forest $)(R 2=0.614, p<0.01)$

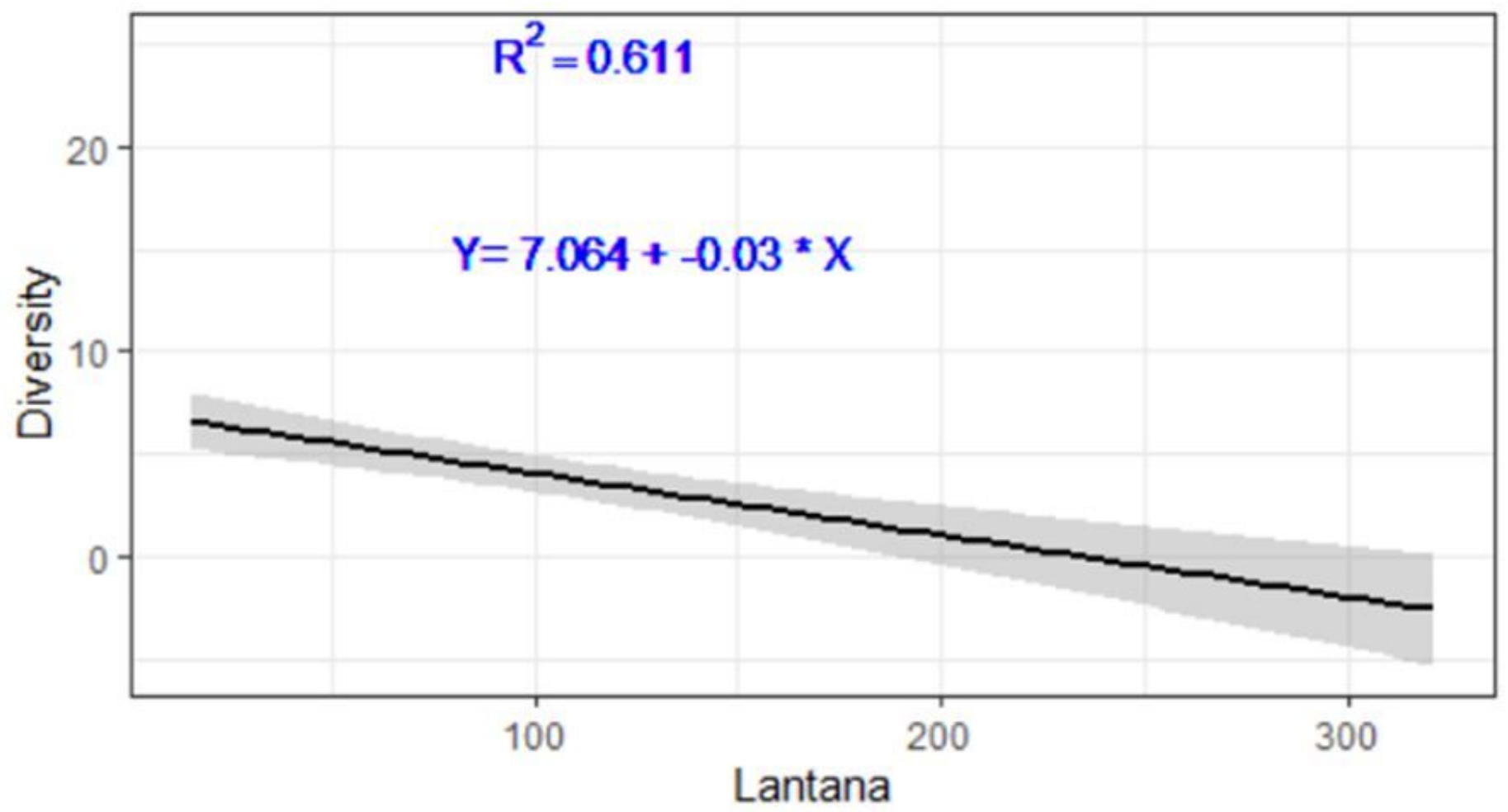


Figure 11

Diversity of Plant species $(Y)$ and Number of Lantana camara per invaded plots $(X)$ (Woze kebele community forest $(R 2=0.611, p<0.01)$.

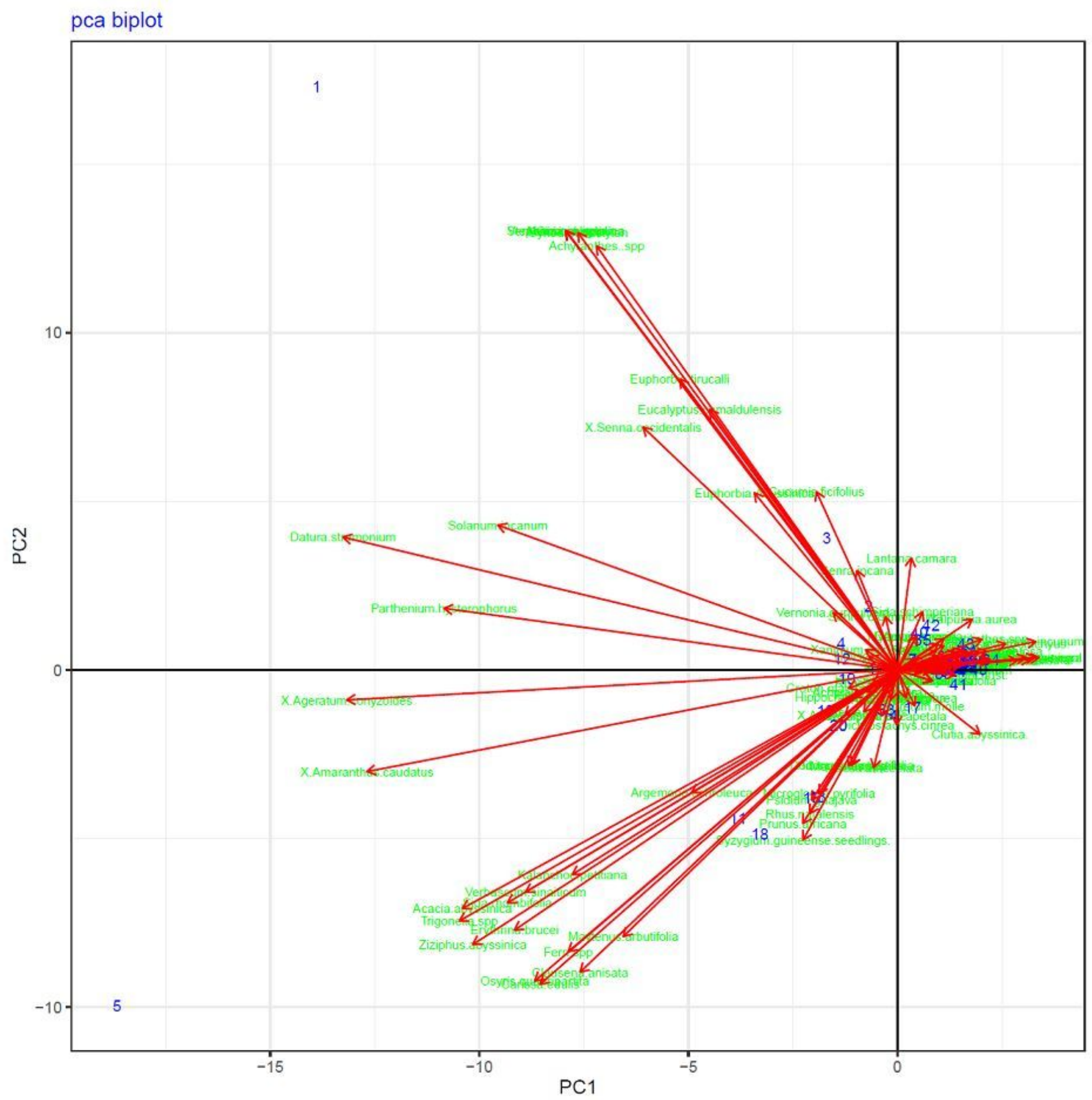

Figure 12

Principal Components Analysis (PCA) ordination diagram of the plots and plant species for non-invaded Floral Communities 


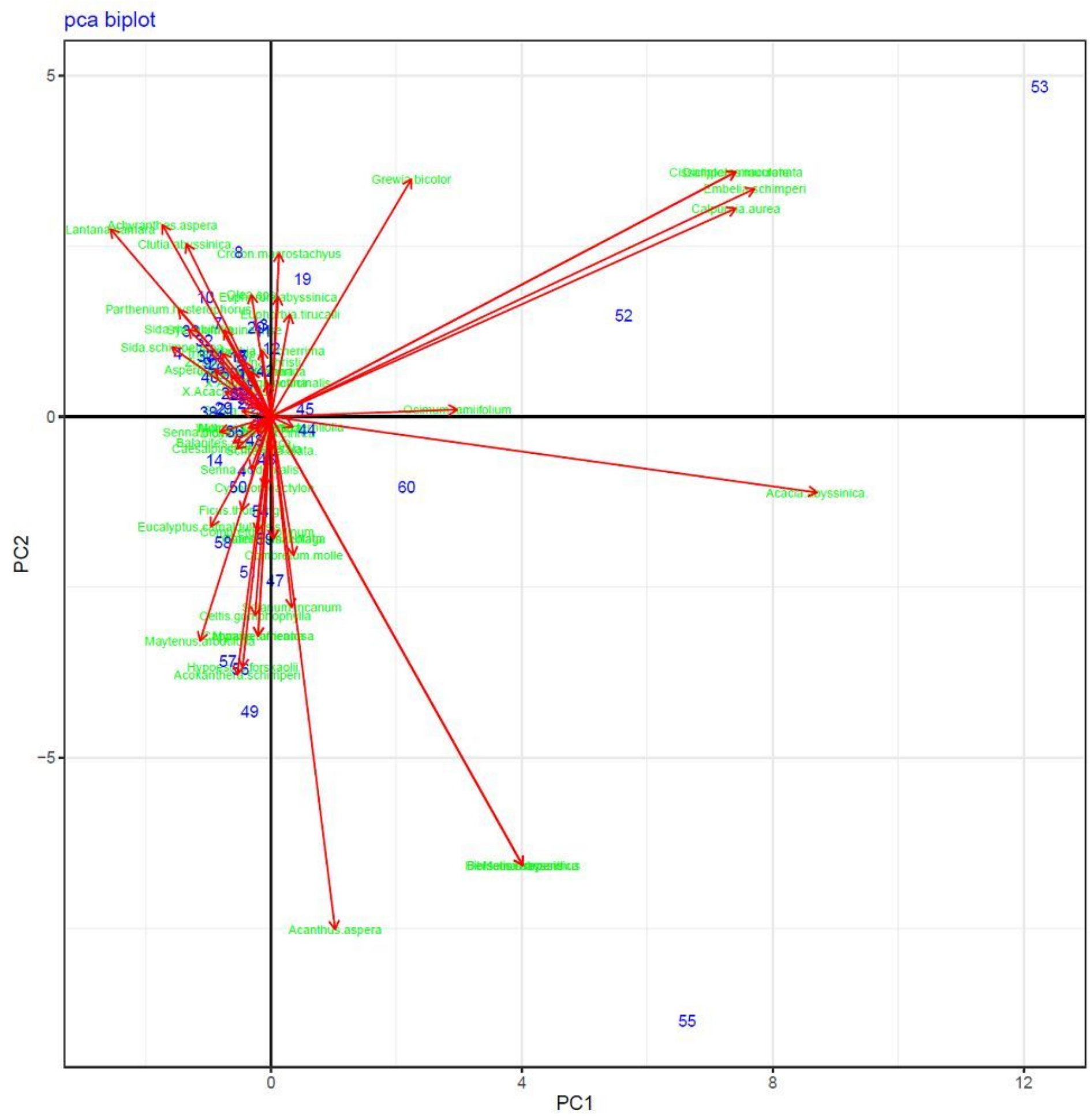

Figure 13

Principal Components Analysis (PCA) ordination diagram of the plots and plant species for invaded floral communities 


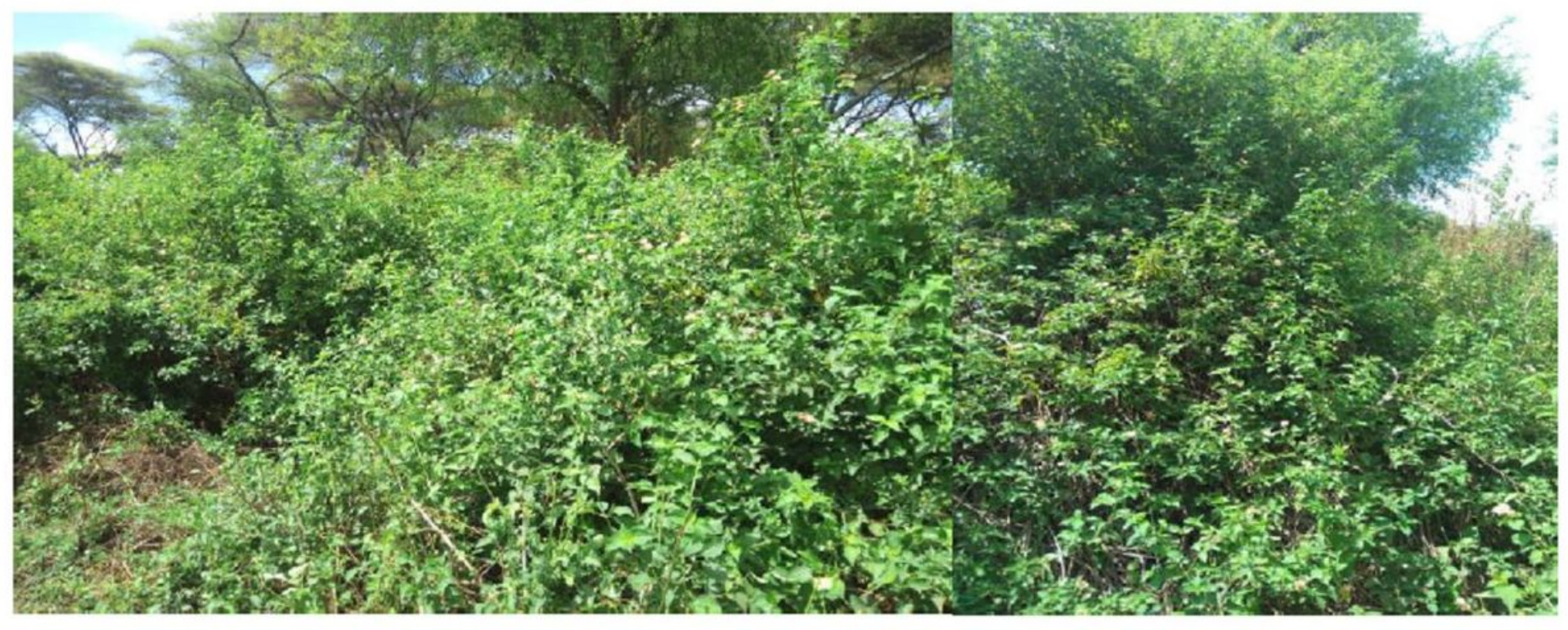

Figure 14

Photo showing Level of Invasion by Lantana camara from Mirab Abaya district (Woze kebele Community forest: - photo taken in April, 2020). 